\title{
Of Rodents and Men: Species-Specific Glucose Regulation and Type 2 Diabetes Research
}

\author{
P. Charukeshi Chandrasekera and John J. Pippin \\ Physicians Committee for Responsible Medicine, Washington DC, USA
}

\begin{abstract}
Summary
Type 2 diabetes mellitus (T2DM) has reached epidemic proportions worldwide and animal models mimicking human T2DM are widely used to study mechanisms of disease and to develop pharmacotherapeutics. Over the last three decades, rodent models of T2DM have yielded more than 50 publications per month; however, many details of human T2DM pathogenesis remain unclear, and means of preventing disease progression remain elusive. This review investigates the reasons for this translational discrepancy by analyzing the experimental evidence from rodent models of T2DM.

The analysis reveals significant species-specific differences at every level of glucose regulation, from gene/protein expression, cellular signaling, tissue and organ to whole organism level, when compared with data acquired using human cells, tissues, organs, and populations. Given the extensive species-specific barrier that creates an immutable translational gap, there is an urgent need to further employ and develop human-based research strategies to make significant strides against the current T2DM epidemic.
\end{abstract}

Keywords: Type 2 diabetes, glucose homeostasis, rodent models, species specificity

\section{Introduction}

Dysregulation of glucose homeostasis can result in serious health consequences, most prominently type 2 diabetes mellitus (T2DM). T2DM has reached epidemic proportions over the last three decades, and it is predicted that by 2030, more than 366 million people worldwide will have T2DM (Wild et al., 2004). In the United States, the prevalence of T2DM is 26 million with another 79 million considered pre-diabetic, and it is estimated that one in three Americans will have diabetes by 2050 (CDC, 2011). Thus it is imperative to develop strategies to understand, prevent, treat, and, hopefully, cure T2DM. In order to achieve these goals, it is necessary to further our understanding of the pathophysiology of this multifactorial disease.

An abundance of animal models displaying various characteristics of T2DM have been generated to study the underlying pathology and to develop potential treatments. These efforts have created a considerable knowledge base regarding rodent glucose biology, from gene regulation to the maintenance of whole-animal glucose homeostasis. However, the precise molecular and biochemical mechanisms leading to disease pathogenesis in humans remain unclear and treatment methods for humans remain unsatisfactory. Erroneous extrapolations from animal research have resulted in poor translational efficacy at every level from molecular mechanistic findings to phenotypic and natural history findings to the development of effective pharmaceuticals. Despite the wealth of knowledge acquired from rodent studies, only a limited number of anti-diabetic drugs are in clinical use for humans, most of which have adverse health effects, but little impact on disease progression, and none of which cures T2DM or clearly prolongs life.

The purpose of this review is to examine the underlying molecular, biological, and physiological differences - from gene regulation to whole-animal and population levels - that help explain why rodents do not serve as reliable models for studying human T2DM. This review will also address how researchers may overcome this translational barrier by employing a wide range of human-based investigational methods that will promote human-relevant discoveries while reducing - and eventually replacing - the use of animals in T2DM research.

\section{T2DM: The characteristic pathophysiology in humans}

The natural history of human T2DM involves a progressive transition from normal glucose regulation to a pre-diabetic stage characterized by impaired fasting glucose and impaired glucose tolerance to T2DM characterized by overt hyperglycemia resulting from a combination of peripheral insulin resistance and $\beta$-cell dysfunction (ADA, 2012; Kahn et al., 2006). Risk factors associated with T2DM in humans include obesity, dyslipidemia, hypertension, lifestyle factors such as physical inactivity and excessive dietary intake, and genetic predisposition (Zimmet et 
al., 2001). T2DM may be foreshadowed by a specific metabolic syndrome that includes abdominal obesity, hypertension, dyslipidemia, impaired fasting glucose, and hypercoagulability. The morbidity and mortality associated with human T2DM - retinopathy, nephropathy, neuropathy, coronary heart disease, peripheral arterial disease, and stroke - derive from dysregulation of glucose homeostasis, in combination with hypertension and dyslipidemia, and the resulting vascular pathologies (Forbes and Cooper, 2013). Elucidating the biochemical mechanistic links among T2DM risk factors, insulin resistance, pancreatic $\beta$-cell dysfunction and T2DM sequelae - as these occur in humans - is therefore key to understanding and treating this disease.

\section{T2DM: Rodent models of human T2DM}

A large number of animal models have been generated to study various aspects of T2DM. A PubMed database search focused on rodent models of T2DM revealed that more than 50 articles per month have been published over the last three decades, allowing for possible duplication among studies (Fig. 1). Rodent species have been preferred since they facilitate progression from hypothesis generation to data acquisition with relative ease in a manageable period of time due to factors such as short breeding periods, short lifespan, ease of use for genetic manipulation, low maintenance cost, and ease of handling.

Obese and non-obese rodent models of T2DM have been generated by several methods, including surgical, chemical, dietary and genetic manipulations, and combinations thereof. The standard surgical approach for producing non-obese models of T2DM is partial or complete pancreatectomy, in which the extent of pancreatectomy appears to determine the severity of the resulting condition (Islam and Loots du, 2009). T2DM is chemically induced in rodents using drugs that destroy pancreatic $\beta$-cells by mechanisms involving irreversible cytotoxicity (Lenzen, 2008). Nutritional modification has been used to model the metabolic disorders characteristic of human obesity, primarily by increasing the fat content in rodent feed (Lutz and Woods, 2012). Genetic models of rodent T2DM can be broadly categorized into two major groups: spontaneous genetically derived models (naturally occurring mutations such as leptin and leptin receptor mutations) and genetically modified models (transgenic, knock-out, and knock-in models). Transgenic models are designed primarily to address the pathophysiological consequences resulting from global or tissue-specific targeted disruption or overexpression of a defined single gene (or multiple genes) on numerous signal transduction pathways involved in glucose homeostasis (Neubauer and Kulkarni, 2006).

These animal models display various phenotypic manifestations of human T2DM, albeit to varying degrees of disease penetrance, severity, and duration. These features include fasting and non-fasting hyperglycemia, reduced pancreatic mass, reduced glucose-stimulated insulin secretion, decreased serum insulin levels, glucose intolerance, dyslipidemias, and obesity (Chatzigeorgiou et al., 2009). However, most rodent models do not replicate the natural history and pathophysiological mecha-

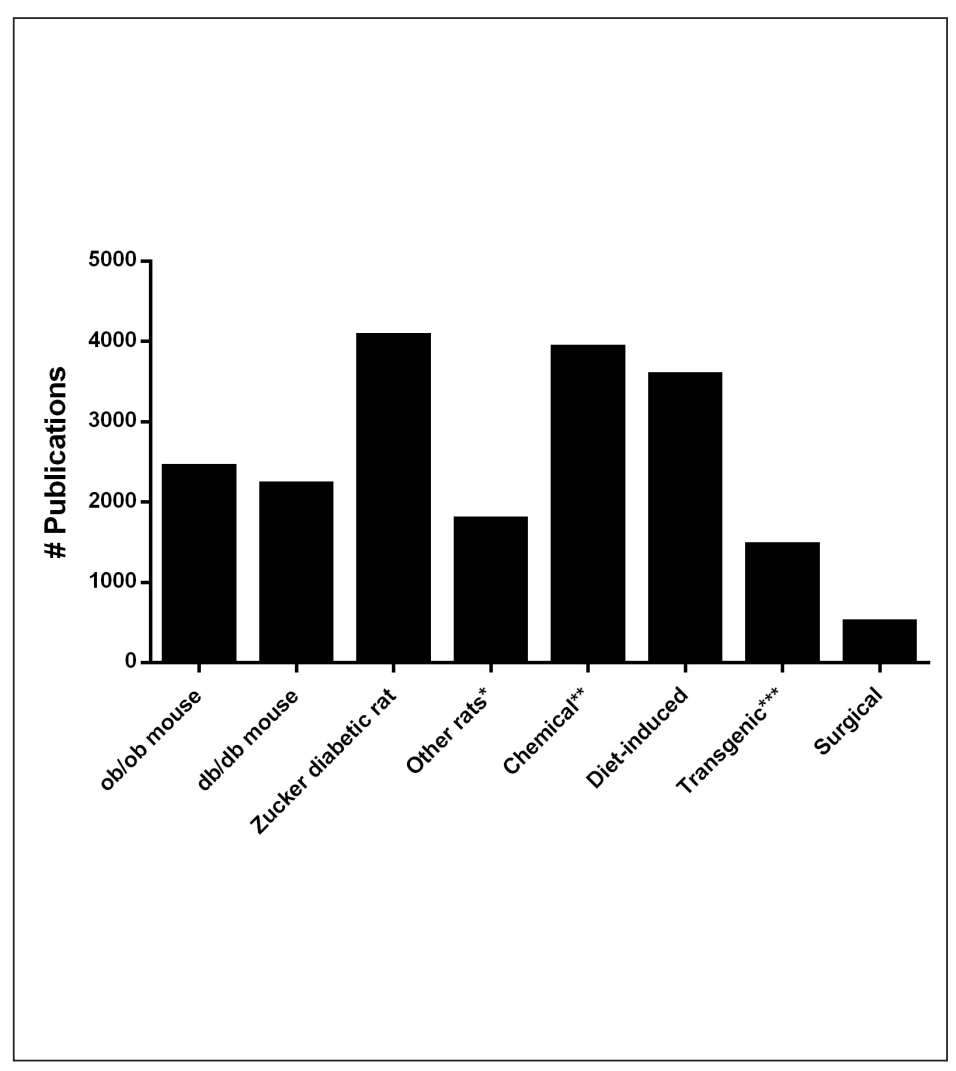

Fig. 1: Scientific publications based on rodent models of type 2 diabetes

The PubMed database was searched to determine the number of papers published with rodent models of T2DM with filters "other animals" and "publication dates" (19822012). For the data shown, relevant papers were obtained using combinations of specific search terms: "model name", "rodents", and "type 2 diabetes." The mean number of rodent studies published monthly was 56 . Please note that this number may vary slightly due to the difficulty in teasing out potential duplication from one category to another. *Other rat models included in this search were GK (Goto-Kakizaki), OLETF (Otsuka Long Evans Tokushima Fatty), and JCR: LA-cp. **Searching for "rodent" diabetes chemically induced with streptozotocin (STZ) and alloxan (ALX) yielded 17,367 and 2,437 , respectively, for a total of 19,804 publications. However, STZ and ALX have been used widely to generate models of type 1 diabetes as well. Therefore, random sampling of references was taken in order to estimate the number of papers that utilized STZ to specifically study T2DM. The results indicate that at least $20 \%$ of the published work can be assigned to the T2DM category. Thus, the value reported here reflects $20 \%$ of 19,804 , but the actual number may be higher. ${ }^{* * *}$ Searching PubMed with the terms "transgenic" and "type 2 diabetes" yields 1466 papers, but is likely higher since many "knock-out" and "knock-in" models may not have been included. 
nisms that lead to the human diabetogenic phenotype, and no individual model or combination of models replicates the complex human T2DM disease state.

\section{From rodents to humans: Species-specificity of glucose biology}

The coordinated function of multiple organs as well as genetic and environmental factors affect $\beta$-cell function and tissue insulin sensitivity, all of which contribute to the etiopathology of this polygenic multifactorial disease in humans. Increased use of human-based methodologies over the last decade has significantly broadened our understanding of the species-specificity of glucose biology. It is now apparent that crucial differences exist at every level of glucose regulation, from gene and protein expression and intracellular signaling to tissue, organ, and whole organism manifestations, and extending to population and environment levels (Fig. 2). Given the breadth of this topic and the extensive literature (Fig. 1), the following sections will address interspecies differences only in tissues and organs that play a direct dominant role in the control of glucose homeostasis - endocrine pancreas, skeletal muscle, liver, and adipose tissue.

\subsection{Glucose biology: Nucleic acid level}

Interspecies differences at the nucleic acid level exist at various stages, including but not limited to chromosomal regulation, orthologous and lineage-specific paralogous gene regulation, tissue-specific transcriptional regulation, total gene (mRNA) expression, and post-transcriptional regulation. Humans have only a single copy of the $\beta$-cell-specific and glucose-regulated insulin gene, located on chromosome 11 (Owerbach et al., 1980). In contrast, rodents are unique compared to all other mammals in that they express two functional forms of insulin from two non-allelic insulin genes. In mice, they are located on chromosomes 19 (gene 1) and 7 (gene 2), and in rats, both insulin genes are located $>100 \mathrm{Mb}$ apart on chromosome 1 (Lomedico et al., 1979; Soares et al., 1985; Wentworth et al., 1986; Davies et al., 1994). In general, rodent insulin gene 2 is thought to be the ortholog of the human insulin gene based on gene structure and sequence homology, but both insulin genes are functionally expressed and regulated in rodents under basal

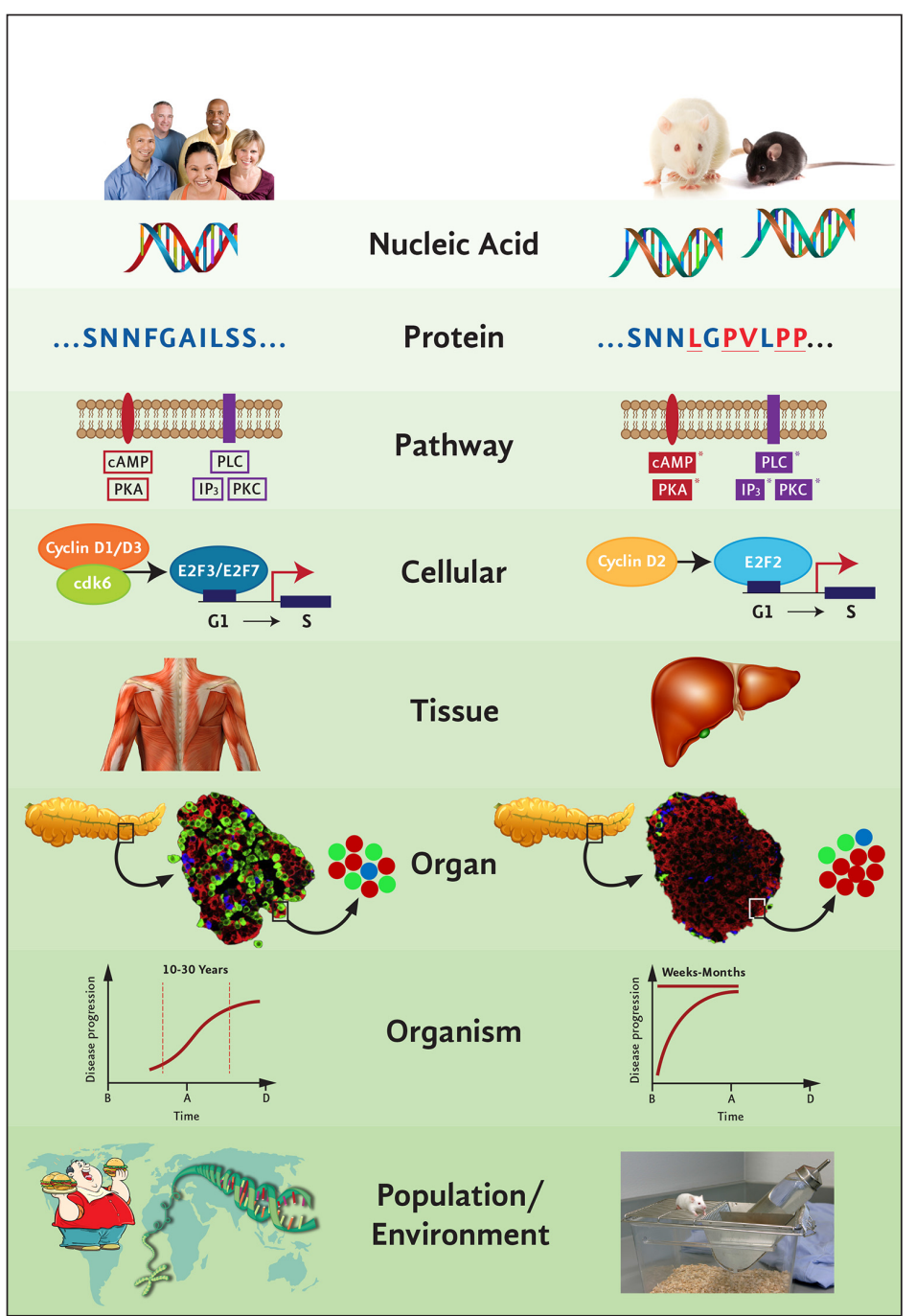

Fig. 2: Species-specificity of glucose regulation This figure illustrates examples of rodent-human speciesspecific differences that exist at every level of glucose regulation, from nucleic acid to environment level: (1) Nucleic acid level - one insulin gene in humans vs two non-allelic insulin genes in rodents; (2) Protein level sequence divergence in rodents in the region that confers amyloidogenicity to human islet amyloid polypeptide;

(3) Pathway level - species disparity in K ATP-independent second phase insulin secretion due to altered signaling via cAMP/PKA and PLC/IP 3 /PKC pathways; (4) Cellular level - control of $\beta$-cell proliferation (G1/S transition) differs in humans; (5) Tissue level - primary site of glucose clearance is skeletal muscle tissue in humans and liver in rodents; (6) Organ level - pancreatic cytoarchitecture is strikingly different and this has functional consequences, as cell-to-cell interactions within the islet markedly vary between humans and rodents; red cells=insulin-secreting beta cells, green cells=glucagon-secreting alpha cells, blue cells=somatostatin-releasing delta cells; (7) Organism level - progressive transition from insulin resistance to overt hyperglycemia over a long period of time in humans versus rapid disease progression and T2DM from birth often observed in rodents ( $B=$ birth, $A=$ adult, $D=$ death); (8) Environment level - uncontrolled life style, epigenetic factors in humans versus controlled laboratory environments for rodents. Refer to text for further details. CAMP-cyclic adenosine monophosphate; PKA-protein kinase A; PLC-

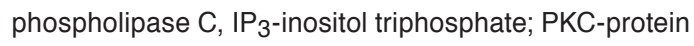
kinase $\mathrm{C}$, KATP-ATP-sensitive potassium channel. Tissue staining images of human and rodent pancreata are reprinted from "Seminars in Cellular and Developmental Biology, Vol 24, Caicedo A, Paracrine and autocrine interactions in the human islet: more than meets the eye, pages 11-21 (2012)", with permission from Elsevier. 
and high glucose concentrations that stimulate insulin biosynthesis (Cordell et al., 1982; Kakita et al., 1982; Wentworth et al., 1986, 1992; Babaya et al., 2006). In addition to primary rodent $\beta$-cells, two functional, glucose-sensitive insulin genes are expressed in the heterologous rodent $\beta$-cell line MIN6, which is widely used to model human $\beta$-cell function in vitro (Roderigo-Milne et al., 2002). Comparative sequence analysis has revealed that the overall homology of the insulin promoter ( -600 to +1 region) between humans and rodents is only $\sim 45-48 \%$. Many features of the cis-regulatory elements, such as the cyclic AMP response element, negative regulatory element, and CCAAT box, also display marked species specificity (Hay and Docherty, 2006; Boam et al., 1990). The exact and relative contributions of the two insulin genes to rodent glucose regulation remain unclear and often overlooked, thereby limiting data extrapolation to the single insulin gene system in humans. These effects may be further amplified since insulin transcriptionally regulates the expression of more than 150 genes in various tissues (Desvergne et al., 2006).

Species-specific differences also occur at proximal trans-acting factor expression and localization, post-translational modifications, DNA binding, and autoregulation. For example, the $\mathrm{V}$-maf musculoaponeurotic fibrosarcoma oncogene homolog (Maf), hepatocyte nuclear factor (HNF), and pancreatic duodenal homeobox 1 (Pdx-1) transcription families play key roles in human and rodent islet and liver transcriptional regulation. However, their expression is differentially regulated in human and mouse islets with respect to spatio-temporal cell type-specific isoform expression and glucose-mediated regulation (Artner et al., 2010; Dai et al., 2012; Hang and Stein, 2011; Dorrell et al., 2011; Harries et al., 2009). Interestingly, mice lacking HNF1a, 1b, and 4a isoforms - genes directly linked to maturity onset diabetes of the young (MODY) in humans - do not emulate human MODY-like phenotypes (Harries et al., 2009).

There is marked divergence in DNA binding between mouse and human glucose regulatory transcription factors. For example, of 4000 orthologous gene pairs tested in human and mouse liver, " $41 \%-89 \%$ of the orthologous promoters bound by a protein in one species were not bound by the same protein in the second species" (Odom et al., 2007). The location of binding events also varied to an extent that could not be predicted from rodent-human sequence alignments, and transcriptional programs in homologous tissues (at least in the liver) appear to be directed by species-specific gene sequences (Odom et al., 2007; Wilson et al., 2008). Autoregulation can also be species-specific: despite significant sequence homology between mouse and human promoter, the CCAAT/enhancer binding protein alpha $(\mathrm{C} / \mathrm{EBP} \alpha)$, a transcription factor critical for regulating liverspecific gene expression (including those of gluconeogenic, cell cycle control, and apoptotic genes), employs a different autoregulatory mechanism in mice (direct binding to a cis element) as compared to humans (indirect trans-acting autoregulation via upstream stimulatory factor) (Schrem et al., 2004; Timchenko et al., 1995).

The above examples provide only a glimpse into the species specificity of the complex gene regulatory networks involved in glucose homeostasis. Although the same families of genes and transcription factors may be involved, differential expression and regulation manifest divergent phenotypes between rodents and humans. With additional regulation by many other factors such as micro RNA (Klein et al., 2013; Lin et al., 2012), chromatin packing and cis-regulatory element-specific chromatin signatures (Mikkelsen et al., 2010), multiple long range interactions (Maston et al., 2006; Sanyal et al., 2012), dimerization (Guo et al., 2010; Mendel et al., 1991), post-translational modifications such as phosphorylation (Hang and Stein, 2011; Guo et al., 2010), and cross-talk among signaling systems (Velloso et al., 2006) - all of which can be species-specific - even subtle differences would have dramatic effects in vivo. Thus, it is important to consider how the cumulative effects of such fundamental differences across the entire gene regulatory network may profoundly limit interspecies translatability.

\subsection{Glucose biology: Protein level}

Rodent and human $\beta$-cells are equipped with glucose transporters and enzymes that play a key role in $\beta$-cell glucose metabolism. The principal glucose transporter present in rodent $\beta$-cells is glucose transporter 2 (GLUT2), and greatly reduced GLUT2 expression levels (both mRNA and protein) have been shown to correlate with elements of T2DM in various diabetic rodent models such as db/db mouse, Goto-Kakizaki rat, Zucker diabetic fatty rat, and streptozotocin mouse (Thorens et al., 1992; Orci et al., 1990; Johnson et al., 1990; De Vos et al., 1995). Based on such evidence, GLUT2 had been presumed to play the same role in the human islet; however, human islets predominantly express glucose transporters 1 (GLUT1) and 3 (GLUT3) (De Vos et al., 1995; McCulloch et al., 2011), and GLUT2 expression levels do not correlate with human T2DM (Ferrer et al., 1995). In fact, T2DM due to decreased $\beta$-cell GLUT2 or defects in GLUT2 may represent only a small subset of humans with T2DM - the well-known inactivating mutations of human GLUT2 are associated with a rare disease of carbohydrate metabolism (Fanconi-Bickel syndrome), which results in significant impairment of hepatic and renal glucose metabolism, but not defective $\beta$-cell insulin secretion (Santer et al., 1998, 1997), with a subset of patients displaying transient neonatal diabetes before the clinical manifestations of Fanconi-Bickel syndrome appear (Sansbury et al., 2012). In marked contrast, mice lacking GLUT2 (GLUT2-null mice and mice expressing GLUT2 antisense RNA in $\beta$-cells) display altered glucose tolerance, loss of first-phase insulin secretion, inverse $\alpha$-to- $\beta$ cell ratio, hyperglycemia, hypoinsulinemia, and increased plasma glucagon, non-esterified fatty acids, and $\beta$-hydroxybutyrate levels. GLUT2 null mice die within the first 2-3 weeks of life following severe growth retardation and impaired postnatal pancreatic development (Valera et al., 1994; Guillam et al., 1997). Biochemically, GLUT2 is a low affinity transporter $(K m \sim 25$ $\mathrm{mM}$ ) while GLUT1 and GLUT3 are high affinity transporters (Km 1-5 mM) (Bell et al., 1993; Bouche et al., 2004). Functionally, this translates into altered glucose sensing and secretion such that human islets secrete more insulin at lower glucose concentrations than mouse islets (Dai et al., 2012) despite the fact that expression levels of glucokinase (the enzyme that catalyzes the rate-limiting step in $\beta$-cell glycolysis) is the same 
in rodents and humans (De Vos et al., 1995). These studies indicate that GLUT2 does not play the same key role in the human pancreas as it does in rodents.

The rate-limiting step in human glucose metabolism is insulin-dependent glucose uptake into skeletal muscle, which is facilitated by glucose transporter 4 (GLUT4) being recruited to the plasma membrane in clathrin-coated vesicles. In humans, the heavy chains of the clathrin triskelion are encoded by two distinct clathrin heavy chain (CHC) genes, $\mathrm{CHC} 17$ and $\mathrm{CHC} 22$ (Kedra et al., 1996). CHC22 is highly expressed in human skeletal muscle, and it is associated with expanded GLUT4 compartments in T2DM patients (Vassilopoulos et al., 2009; Wakeham et al., 2005). Unlike in humans, only a pseudogene exists in mice (Wakeham et al., 2005; Vassilopoulos et al., 2009). In addition, CHC22 appears to be biochemically and functionally distinct with unique protein-protein interactions and transport properties (Wakeham et al., 2005; Brodsky, 2012). For example, $\mathrm{CHC} 22$ does not bind the classic adapter proteins or Golgilocalized, $\gamma$-ear-containing Arf-binding proteins that $\mathrm{CHC} 17$ interacts with, but directly binds to the membrane cargo recognition family member sorting nexin 5 abundant in skeletal muscle through a coiled-coil domain absent in CHC17 (Towler et al., 2004a,b). GLUT4 translocation has been studied extensively in mice with the goal of understanding the role of insulinmediated glucose uptake in T2DM, but translatability is limited due to species differences in the GLUT4 trafficking pathway.

In terms of pathophysiological features of human T2DM at the protein level, one of the most striking differences in rodents is the absence of islet amyloid deposits. Islet amyloid polypeptide (IAPP) is a 37-amino acid peptide that in humans is coexpressed and co-secreted in a 1:1 ratio with insulin. IAPP and insulin genes have similar promoter elements, and IAPP transcription is regulated by the same transcription factor utilized by insulin promoter in a glucose-dependent manner (Lukinius et al., 1989; Watada et al., 1996; Macfarlane et al., 2000). One of the primary reasons for $\beta$-cell apoptosis and decreased $\beta$-cell mass in human T2DM is the accumulation of extracellular oligomeric fibrils of IAPP, which disrupt membrane interactions (cell-to-cell adherence and coupling), induce apoptosis, impair insulin secretion, and lead to progressive $\beta$-cell failure (Haataja et al., 2008; Ritzel et al., 2007). In contrast, rodent IAPP exists in monomeric form and does not form oligomers or amyloid deposits (Westermark et al., 2011); rodents, therefore, do not fully recapitulate this important aspect of human T2DM islet pathology. The amino- and carboxy-terminals of IAPP display high homology between humans and rodents, but due to the presence of proline residues in the serine-rich region that confers human IAPP its amyloidogenic properties (residues 20-29, Fig. 2), rodent IAPP is not amyloidogenic (Westermark et al., 1990). Many attempts have been made to create amyloidogenic islets in rodents by transgenic expression of human IAPP; however, the results were highly variable with limited similarity to human IAPP pathophysiology (Matveyenko and Butler, 2006). From pancreatic glucose sensing to skeletal muscle glucose transport to loss of $\beta$-cell mass, human and rodent proteins (and their biological effects) have diverged significantly to an extent that does not permit reliable interspecies extrapolation.

\subsection{Glucose biology: Pathway level}

Rodent-human species differences are also seen in cellular signal transduction and glucose metabolic pathways. Glucose metabolism via anaplerosis and cataplerosis plays an important role in insulin secretion by rodent pancreatic $\beta$-cells, and metabolic enzymes pyruvate carboxylase and ATP citrate lyase play important roles in rodents. However, the levels and activities of the key anaplerotic enzymes pyruvate carboxylase and ATP citrate lyase are reported to be $80-90 \%$ and $60-75 \%$ lower in human islets compared to rodent islets, respectively (MacDonald et al., 2011). The role of pyruvate carboxylase in insulin secretion in human islets is also different from rodents: human islets are less dependent on pyruvate carboxylation, with only $15 \%$ pyruvate carboxylation activity compared to that in rodents. Furthermore, glucose-stimulated human islets form more acetoacetate than rodent islets, and human islets also contain higher levels of other metabolic enzymes such as succinyl-CoA-3-ketoacidCoA transferase and acetoacetyl-CoA synthetase (MacDonald, 2002). Fatty acid synthase levels in human islets are also higher than in rodent islets (MacDonald, 2002). Glucose-6-phosphatase (G6P) plays an indispensable role in rodent and human liver by catalyzing the final step in gluconeogenesis and glycogenolysis; however, unlike murine G6P, human G6P catalytic subunit gene expression is not subject to modulation by peroxisome proliferator activated receptor gamma coactivator-1 via HNF4a due to a mere 3-base-pair sequence variation (Schilling et al., 2008). Such differences in critical glucose metabolic pathways between rodents and humans have fundamental implications for understanding the regulation of human glucose homeostasis under normal and disease conditions.

Insulin secretion is the end result of a coordinated effort by a host of signaling molecules from various intracellular signaling cascades. The secretory responsiveness characteristic of human perfused pancreas and perifused islets includes biphasic insulin secretion (a rapid robust first phase and a sustained rising second phase) as well as time-dependent potentiation and inhibition of insulin secretion (Nesher and Cerasi, 2002; Grodsky, 1989; Eizirik et al., 1992). In marked contrast, perfused and perifused mouse islets lack the sustained second phase and the time-dependent potentiation and inhibition responses to priming with high glucose. Moreover, mice also differ from rats in this regard, as rat islets readily display biphasic insulin release and time-dependent potentiation/inhibition (Berglund, 1980, 1987; Zawalich and Zawalich, 1996a; Zawalich et al., 1998). This species disparity in ATP-sensitive potassium (KATP) channel-independent second phase insulin secretion can be attributed - at least in part - to altered intracellular signaling pathways involving cAMP (Ma et al., 1995), ATP and protein kinase A (Takahashi et al., 1999), glyceraldehyde (Lenzen, 1979), amino acids (Liu et al., 2003), and phospholipase C/protein kinase C (Zawalich et al., 2000, 2001, 1995; Zawalich and Zawalich, 1996b). Studies with humans have shown that in T2DM, the first-phase insulin secretion is almost abolished and the second-phase insulin secretion is significantly reduced (Del Prato, 2003). Notably, insulin secretion in the conscious mouse is biphasic and pulsatile, and thus it has been argued that the mechanism(s) generating the murine second phase response in vivo is lost during in vitro islet dis- 
sociation (Nunemaker et al., 2006). This would complicate interspecies extrapolation by raising the possibility that mice may contain a labile signaling factor absent in humans and rats.

Pronounced species differences in islet glucose sensitivity can substantially affect drug testing. This may be particularly true for drugs that are targeted to intracellular signaling cascades to improve glucose-dependent insulin secretion. For example, drugs targeted to $\mathrm{G}$ protein-coupled receptor 119 and incretins that increase insulin secretion via cAMP/PKA-mediated pathways may exert variable results in rodents. In addition, even subtle changes in the signal transduction network can generate differential effects. For example, the activation of adenosine monophosphate-activated protein kinase by the most widely prescribed anti-diabetic drug, metformin, is more potent in primary human hepatocytes compared to primary rodent hepatocytes despite similar intracellular ratios of adenosine monophosphate and adenosine triphosphate (Stephenne et al., 2011). Taken together, the cumulative effects of alterations in key signaling molecules and their intrinsic properties within the human cellular milieu (further affected by post-translational modifications, subcellular localization, kinetics, feedback mechanisms, and cross-talk, etc.) can result in distinct signaling events in diverse cellular contexts that cannot be reliably extrapolated across the species barrier.

\subsection{Glucose biology: Cellular level}

Pancreatic dysfunction concomitant with a decrease in $\beta$-cell mass is a key feature of human T2DM, and therefore much effort has been dedicated to studying $\beta$-cell survival and replication for $\beta$-cell replacement therapy. There is ample evidence depicting the ability to robustly induce adult murine $\beta$-cell replication in vitro, but such replication rarely occurs in adult human $\beta$-cells (Butler et al., 2003; Parnaud et al., 2008). In the murine $\beta$-cell $\mathrm{G}_{1} / \mathrm{S}$ proteome, the $\mathrm{E} 2 \mathrm{~F} 2$ protein is abundantly expressed, and loss of E2F2 expression by gene knockout leads to severe pancreatic dysfunction (Iglesias et al., 2004). However, human islets lack E2F2, but contain E2F3 and E2F7 that are absent in murine islets (Fiaschi-Taesch et al., 2009). The cyclin family members involved in cell cycle progression also differ: humans primarily express cyclin D3 with variable amounts of cyclin D1, and little or no cyclin D2, but rodents express and utilize cyclin D2 to an extent that rodents lacking cyclin D2 develop islet hypoplasia, hypoinsulinemia, and diabetes (Fiaschi-Taesch et al., 2010). Similarly, expression of cdk-6 (a protein kinase of the CDK family that is critical for $\mathrm{G}_{1}$ progression and $\mathrm{G}_{1} / \mathrm{S}$ transition) markedly varies between human and murine islets. Human $\beta$-cells express cdk- 4 and cdk- 6 , the latter capable of promoting robust human $\beta$-cell proliferation, which is in marked contrast to murine islets that do not express cdk-6 (Fiaschi-Taesch et al., 2010). In terms of cell survival, there are species-specific differences in the role calcineurin plays for $\beta$-cell survival: inhibition of calcineurin induces marked human $\beta$-cell apoptosis, but only moderates murine $\beta$-cell proliferation (Soleimanpour et al., 2010). The translation of $\beta$-cell survival and replication in mouse models to $\beta$-cell survival and islet transplantation in humans, with a different complex of cell cycle proteins and regulatory pathways, is poor.
The trademark biological function that defines a pancreatic $\beta$-cell is its ability to secrete insulin in response to glucose. Recent evidence obtained using human islets suggests that human $\beta$-cell stimulus-secretion coupling differs greatly with respect to ion channel composition and function. Both rodent and human $\beta$-cells express the voltage-gated $\mathrm{K}_{\mathrm{ATP}}$ channels, the primary glucose sensors that initiate $\beta$-cell stimulus-secretion coupling. Polymorphisms in the $\mathrm{K}_{\mathrm{ATP}}$ channel subunit genes have been associated with increased risk of T2DM in humans. In addition, loss-of-function mutations in either of the K $\mathrm{K}_{\text {ATP }}$ channel subunits, sulfonylurea receptor type 1 (SUR1) or inwardly rectifying $\mathrm{K}^{+}$channel ( $\mathrm{K}_{\text {ir }} 6.2$ ), cause severe dysregulation of insulin secretion leading to persistent hyperinsulinemic hypoglycemia of infancy (Denton and Jacobson, 2012). Unlike humans, SUR1ablated mice remain euglycemic with normal insulin secretion in response to feeding (Shiota et al., 2002). This is due, in part, to the activation of a cholinergic response that compensates for the severe defects in glucose-induced insulin secretion mediated by SUR1 (Shiota et al., 2002), but such compensation does not occur in humans with SUR1 inactivation. Similarly, $\mathrm{K}_{\mathrm{ir}} 6.2$ null mice have no $\mathrm{K}_{\mathrm{ATP}}$ channel activity in $\beta$-cells, but show only mild impairment in glucose tolerance (Miki et al., 1998). It is instructive that genetic deletion of such genes critical for insulin secretion in mice does not always result in deleterious consequences nor manifest the same way as in humans.

The repertoire of other voltage-gated ion channels involved in stimulus-secretion coupling also differs between mice and humans. Human $\beta$-cells express functionally important $\mathrm{Ca}^{2+}$ channels that are not thought to be as critical in the mouse $\beta$-cell (Braun et al., 2008). For example, R-type $\mathrm{Ca}^{2+}$ channels, which play a critical role in mouse $\beta$-cells by modulating the kinetics of insulin release and glucose-mediated suppression of glucagon secretion, are not expressed at detectable levels in human $\beta$-cells (Jing et al., 2005; Rorsman and Braun, 2013). The expression of voltage-gated delayed rectifier potassium channels that regulate exocytosis and delayed phase ionic current in humans also differs in rodents. Voltage-gated $\mathrm{Na}^{+}$channels $\left(\mathrm{Na}_{\mathrm{v}}\right)$ are expressed in mouse $\beta$-cells, but there is no functional $\mathrm{Na}^{+}$current at physiological membrane potential $(-80 \mathrm{mV})$ due to voltage-dependent inactivation. In marked contrast, human $\beta$-cells carry voltage-gated $\mathrm{Na}^{+}$current (via $\mathrm{Na}_{\mathrm{v}} 1.6$ isoform and Nav1.7) important for action potential generation and glucosemediated insulin secretion (Braun et al., 2008). Functional implications of such discoveries cannot be understated given the diverse roles of ion channels like $\mathrm{Na}_{\mathrm{v}} 1.7$. For example, $\mathrm{Na}_{v} 1.7$ is involved in nociception (Dib-Hajj et al., 2013), and any $\mathrm{Na}_{\mathrm{v}} 1.7$ antagonists developed for use as analgesics could have serious implications for human patients who face potential impairment of insulin secretion as a side effect, an effect that would not be readily evident in mice since they lack functional $\beta$-cell Nav1.7.

The expression and function of plasma membrane receptor and intracellular ion channel complements facilitating voltageindependent insulin release also differ between rodents and humans. Extracellular ATP provides an important autocrine regulatory mechanism that enhances the sensitivity and responsiveness of the human $\beta$-cell to glucose (Jacques-Silva et al., 
2010). Human $\beta$-cells evoke this response predominantly via ion channel-gated, ATP-selective P2X purinergic receptors, particularly $\mathrm{P}_{2} \mathrm{X}_{3}$ subtype (Jacques-Silva et al., 2010). In contrast, rodent $\beta$-cells primarily act via biochemically, pharmacologically, and functionally distinct, G-protein coupled P2Y purinergic receptors (Petit et al., 1998; Farret et al., 2004; Leon et al., 2005; Poulsen et al., 1999). Intracellular signaling via the ubiquitous second messenger $\mathrm{Ca}^{2+}$ is an important aspect of $\beta$-cell stimulus-secretion coupling. Receptor-mediated $\mathrm{Ca}^{2+}$-signaling involves the release of $\mathrm{Ca}^{2+}$ from intracellular stores through inositol triphosphate $\left(\mathrm{IP}_{3}\right)$ and ryanodine receptors (RyR), and there is interspecies variation in expression levels and isoforms (Zawalich et al., 2001; Rorsman and Braun, 2013; Zhang et al., 2007; Johnson et al., 2004). In rodents, $\beta$-cell intracellular $\mathrm{Ca}^{2+}$ generates synchronized oscillations that spread throughout the islet (Valdeolmillos et al., 1989; Santos et al., 1991; Jonas et al., 1998; Poulsen et al., 1999). In contrast, islet-wide synchronized $\mathrm{Ca}^{2+}$ oscillations do not occur in humans (Cabrera et al., 2006). Examination of fundamental cellular activities - from human $\beta$-cell division to stimulus-secretion coupling to $\beta$-cell survival - reveals major species differences in the $\beta$-cell machinery and mechanisms.

\subsection{Glucose biology: Tissue level}

Skeletal muscle comprises the primary site of glucose clearance in humans, accounting for $50 \%-90 \%$ of glucose uptake, making it the primary insulin-sensitive tissue and the primary site of dysregulation in human peripheral insulin resistance (Shulman et al., 1990; DeFronzo and Tripathy, 2009; Koistinen and Zierath, 2002; Abdul-Ghani and DeFronzo, 2010). By contrast, liver is the primary site of glucose clearance in rodents, with 5 to 10 -fold higher glycogen storage in the liver in rodents versus $\sim 10$-fold more glycogen storage in muscle than in liver in humans (Ivy, 1999; Kasuga et al., 2003). This has functional implications since various aspects of glucose regulation differ between human skeletal muscle and rodent liver. For example, human skeletal muscle glucose transport is primarily facilitated by high affinity GLUT4 while rodent liver glucose transport is primarily facilitated by low affinity GLUT2. Glucose transport is the rate-limiting step in human skeletal muscle glucose metabolism whereas the ratelimiting step in rodent liver is glucose phosphorylation (Petersen and Shulman, 2002; Ploug and Vinten, 2006). Moreover, exercise can greatly increase glucose uptake and glycogen synthesis in skeletal muscle in a manner similar to that mediated by insulin, but liver does not display such exercise-mediated glucose transport (Jensen and Richter, 2012).

Impaired glucose trafficking in skeletal muscle is the primary cause of insulin resistance and an important element for development of T2DM in humans. Skeletal muscle tissue from human subjects with T2DM has significantly reduced GLUT4 expression, and real-time evaluation of molecular defects using magnetic resonance spectroscopy has also revealed that insulin resistance in humans can result from decreased insulin-stimulated GLUT4 activity and subsequent glycogen synthesis (Cline et al., 1999; DeFronzo and Tripathy, 2009; Del Prato et al., 1994). In contrast, rodents lacking GLUT4 (global GLUT4-null) do not develop hyperglycemia (Katz et al., 1995). Furthermore, mus- cle-specific GLUT4 knockouts also show that lack of muscle GLUT4 does not impair glycemic control in mice (Fam et al., 2012). Additionally, unlike in humans, reduced glucose uptake in rodents appears to result not from decreased GLUT4 levels, but rather from impaired GLUT4 translocation and reduced GLUT4 availability at the cell surface (King et al., 1992; Hansen et al., 1998). Interestingly, compared to wild type controls, knockouts lacking muscle-specific glycogen synthase disposed glucose more effectively, and had normal glucose levels and better glucose tolerance (Pederson et al., 2005), further implicating the reliance on other organs for rodent glucose disposal. Perturbation of insulin signaling through tissue-specific deletion of the insulin receptor in muscle does not alter glucose homeostasis in mice these mice display normal blood glucose levels, serum insulin levels, and glucose tolerance (Bruning et al., 1998). However, liver-specific deletion of insulin receptor causes severe insulin resistance with marked hyperinsulinemia, hyperglycemia, and glucose intolerance in mice (Michael et al., 2000). In addition, liver-specific deletion of insulin receptor substrate 1 and 2 also causes insulin resistance (Kubota et al., 2008).

Obesity is a major risk factor for human insulin resistance and type 2 diabetes. Adipose tissue plays a central role in the regulation of obesity and metabolism by modulating the release of non-esterified fatty acids (increased lipolysis), glycerol, hormones such as adiponectin and leptin, and pro-inflammatory cytokines, and other factors contributing to human insulin resistance (Kahn et al., 2006). Human and rodent adipose tissue regulation has diverged on various fronts from adipogenesis to adipokine secretion. For example, a recent study has shown that major species differences exist in the signaling pathways which promote adipogenesis by modulating the master regulator of adipogenesis, peroxisome proliferator-activated receptor $\gamma$ $(\operatorname{PPAR} \gamma)$. Human adipogenesis appears to be critically dependent on the modulation of the PPAR $\gamma$ axis by glucocorticoiddependent gene LIM domain only 3 (LMO3). However, mouse LMO3 does not have the same functional consequences due to mutations in the critical glucocorticoid induction site GRE1 in the mouse genome (Lindroos et al., 2013).

Adipocyte PPAR $\gamma$ binding sites also vary between humans and rodents - there is low retention of binding sites between species, and the binding site specificity is also dependent on the context. In humans, binding retention appears to depend on "actual sequence conservation and chromatin context" whereas retention in mice is dependent more on "vicinity to highly expressed genes, co-binding with $C / E B P \alpha$, and binding strength" (Schmidt et al., 2012). Also at variance in adipose tissue signaling is the regulation of adipocyte glucose sensing and systemic glucose metabolism via the adipokine retinol binding protein-4 (RBP4). Expression and regulation of adipose and circulating RBP4 markedly varies between human and mouse obesity (Janke et al., 2006). Taken together, species specificity - from adipose tissue gene expression to adipokine regulation - can affect translatability from mechanistic findings to drug development. PPAR isoforms have been the target of the thiazolidinedione class of anti-diabetic drugs, and the combined effect of these species differences may contribute to the lack of efficacy and the various drug toxicities seen in humans. 


\subsection{Glucose biology: Organ level}

For decades it had been assumed that human pancreatic islet cytoarchitecture is similar to that in rodents. While human and rodent islets contain the same cell types, in rodent islets, there is clear segregation of different cell types characterized by predominant $\beta$-cells ( $70-80 \%)$ clustering in the center with a characteristic "mantle-core" pattern, in which the core of $\beta$-cells is surrounded by a mantle of $\alpha$-cells (along with other islet cell types, $\delta$ and $\gamma$ ) localized to the periphery of the islet (Baetens et al., 1979; Bennett et al., 1996; Ku et al., 2002). Comprehensive analysis of human pancreatic islet composition by confocal laser scanning microscopy and multiple immunofluorescence labeling has shown that human islet cytoarchitecture is strikingly different. Human $\alpha$-cells are not discretely localized to the periphery, and the vast majority of human $\beta$-cells intermingle with all other cell types compared to the homotypic associations prominent in mouse $\beta$-cells (Brissova et al., 2005; Cabrera et al., 2006; Kim et al., 2009), other than in one study that identified some small human islets displaying mouse-like segregation (Bosco et al., 2010). The relative islet cell composition also varies between rodents and humans. Image analysis of human islet optical sections and morphometric analysis of discrete histological sections have shown that human islets contain (with slight variations among studies) approximately $50-60 \% \beta$ cells, $30-40 \% \alpha$ cells, and $10 \% \delta$ cells in contrast to $>70 \% \beta$ cells, $<20 \% \alpha$ cells, and $<10 \% \delta$ cells in rodents (Brissova et al., 2005; Cabrera et al., 2006).

Islet architecture also differs with respect to vasculature and innervation. Human islets have a more prominent intra-islet vasculature with higher smooth muscle content. In contrast, rodent islet vasculature is primarily composed of endothelial tubes, with only a few arterioles containing smooth muscle cells (Bonner-Weir and Orci, 1982; Rodriguez-Diaz et al., 2011a). Islet $\beta$-cells in mice directly interact with vascular endothelial cells, which contain a single basement membrane. In contrast, human capillary endothelia have two separate sheaths of basement membranes, generating altered molecular interactions between islet and endothelial cells (Otonkoski et al., 2008).

It has long been known that rodent islets are densely innervated with sympathetic, parasympathetic, and sensory nerves with less innervation in the exocrine pancreas (Ahren, 2000). In contrast, human islets display sparse innervation with only a few neuronal axons penetrating the islet (and only in discrete regions within the islet), while much denser innervation is present in the exocrine pancreas (Rodriguez-Diaz et al., 2011a; Caicedo, 2012). In mouse islets, sympathetic fibers preferentially innervate $\alpha$-cells while parasympathetic fibers innervate $\alpha$ - and $\beta$-cells equally. In contrast, the sympathetic axons do not innervate or contact human islets directly - they innervate contractile "vascular smooth muscle cells deep inside human islets" (Rodriguez-Diaz et al., 2011a). Thus, in humans, sympathetic nerves regulate islet function indirectly by controlling blood flow or by acting on islet regions located downstream, whereas mouse islets are directly innervated by the autonomic nervous system (Rodriguez-Diaz et al., 2011a), introducing a different set of mechanisms to regulate islet function and subsequent glucose metabolism.
Morphological differences translate into functional differences between human and rodent islets at many levels. For example, in human islets, $\alpha$-cells appear to exert stronger influence on $\beta$-cells compared to rodent islets due to the higher proportion of $\alpha$-cells and their unstructured association with $\beta$-cells. In the human islet, $\alpha$-cells store, exocytose, and secrete acetylcholine via the vesicular acetylcholine transporter under lower glucose concentrations, and this endogenous acetylcholine in turn "primes" the juxtaposed $\beta$-cells for fluctuations in glucose levels by amplifying $\beta$-cell-specific glucose-induced insulin secretion (Rodriguez-Diaz et al., 2011b). With only a small number of $\alpha$-cells juxtaposed to $\beta$-cells, this paracrine nonneural cholinergic activity of human islets cannot be modeled in rodent islets. Instead, mouse islets are densely innervated by cholinergic axons, and acetylcholine exerts direct neural effects on insulin secretion via M3 muscarinic receptors expressed on $\beta$-cells (Gilon and Henquin, 2001; Gautam et al., 2007).

The cumulative effects of islet architecture and signaling appear to identify human islets as unique. Human islets have a different set-point for glucose sensing, with a lower threshold for insulin secretion (Rorsman and Braun, 2013). The magnitude of glucose-induced insulin secretion is much lower in human islets (3-fold) compared to rodent islets (30-fold) (Dai et al., 2012). Of note, the insulin secretory capacity differs not only between humans and rodents, but also among rodent species and strains (Lenzen, 1979). In addition to insulin secretion, glucagon secretion and subsequent effects also differ among species, and postulations regarding "glucagonocentric" diabetes should be based solely on human studies, as "[important] species differences in the $\alpha$-cell stimulus secretion coupling as well as in the relative importance of the different components of the signaling networks have significantly hampered our ability to propose a unifying hypothesis for regulation of glucagon secretion" (Gromada et al., 2007). With $70-80 \%$ of $\beta$-cells juxtaposed to $\alpha$-cells in humans, intra-islet insulin secretion prevents hyperglucagonemia, and unregulated $\alpha$-cells hypersecrete glucagon, thereby generating a diabetic phenotype (Unger and Cherrington, 2012), whereas these interactions are different in rodents with different pancreatic cytoarchitecture (cell-to-cell interactions and innervation, as described above). Taken together, these findings indicating marked differences in islet architecture and function raise heretofore under-appreciated concerns regarding the species specificity of glucose biology and subsequent translatability, especially with respect to treatment modalities for human T2DM. These differences may partly explain why many treatments shown to reverse diabetes in rodents have not translated to humans.

\subsection{Glucose biology: Organism level}

One hallmark feature of human T2DM is the progressive transition from pre-diabetic metabolic dysfunction to insulin resistance and reduced $\beta$-cell compensation and failure, eventually leading to T2DM with overt hyperglycemia (Kahn et al., 2006). Due to the nature of rapid experimental induction of dysglycemia, insulin resistance does not precede hyperglycemia in many rodent models, and overt hyperglycemia can be present without elevated plasma insulin or insulin resistance (Srinivas- 
an and Ramarao, 2007). Most rodent models do not allow the researcher to control the onset or the severity of insulin resistance, and the inability to accurately model human disease progression becomes problematic, especially when developing therapies for the early phase of human T2DM. Systemic glucose regulation is also subject to further modulation by cross-talk among parallel systems. For example, estrogen exerts various effects on skeletal muscle, liver, adipose tissue, and cells of the immune system; and estrogen action on the pancreas can regulate insulin secretion (Mauvais-Jarvis et al., 2013). Such interactions introduce another level of species-specific differences, hindering rodent-to-human extrapolation.

Human T2DM is associated with vascular complications, which start developing long before the clinical diagnosis of overt hyperglycemia. One of the primary limitations of rodent models of T2DM is that they either lack these complications altogether or do not mirror the human etiopathology accurately. Cardiovascular complications remain the leading cause of morbidity and mortality in human T2DM, with accelerated atherosclerosis being the dominant underlying mechanism. It is well-known that an altered lipid profile, characterized by elevated total cholesterol and low-density lipoprotein (LDL) and decreased high-density lipoprotein (HDL), and other factors such as inflammation, oxidative stress, and insulin resistance contribute to the chronic complex process of atherosclerosis in humans (Van Gaal et al., 2006). However, rodents are resistant to atherosclerosis in general - atherosclerosis is typically absent or very mild unless specific atherogenic manipulations are enforced with diet and/or genetic modifications (Pellizzon, 2008; Ishibashi et al., 1994; Coleman et al., 2006; Daniels et al., 2012). Rodents have highly effective lipid clearance and a notably different anti-atherogenic lipid profile where HDL is the major lipoprotein in circulation rather than LDL. Mouse strains differ considerably in their susceptibility to atherosclerosis, and some strains resist atherosclerosis even when fed atherogenic diets (Pellizzon, 2008; Galman et al., 2007; Ishida et al., 1991; Nishina et al., 1994; Jiao et al., 1990; Mu et al., 1999).

Furthermore, platelet aggregation, a major component of the human atherosclerotic process, is not a critical factor in rodent models. Notably, one of the most widely used mouse models of T2DM, the $\mathrm{db} / \mathrm{db}$ model, which has generated more than 2,300 publications over the last three decades (Fig. 1), does not readily develop atherosclerotic lesions despite obesity, hyperlipidemia, and cardiomyopathy (Belke et al., 2004). The $\mathrm{db} / \mathrm{db}$ mouse develops atherosclerosis only on a highly atherogenic diet or when crossed into a vulnerable genetic background such as apolipoprotein E-deficient mice (Wendt et al., 2006). However, such manipulations do not follow the same etiology as in humans. In addition, the method of T2DM induction in rodents can often induce irrelevant cardiovascular abnormalities such as decreased blood pressure and resting bradycardia observed in streptozotocin-induced rodent T2DM models (Hicks et al., 1998). In terms of other diabetic complications, most rodent models lack overt degenerative pathological alterations seen in human diabetic neuropathy, which include segmental demyelination and axon loss (Sharma and Thomas, 1974). Similarly, rodents may develop early stages of diabetic retinopathy, but intravitreal neovascularization leading to blindness in humans is not seen in any rodent model of T2DM (Robinson et al., 2012). Instead of diabetic complications inherent in humans, rodents tend to develop other secondary - often lethal - conditions such as ketoacidosis, growth retardation, and neonatal mortality, which are absent in human T2DM (Srinivasan and Ramarao, 2007).

Rodents also develop unrelated pathophysiological complications that arise due to the technique of induction. For example, induction of T2DM using the toxic glucose analogues streptozotocin and alloxan also results in extrapancreatic genotoxic and cytotoxic effects including disruption of the hypothalamic-pituitary-gonadal axis (Szkudelski et al., 1998; Thliveris et al., 1984), and therefore it is often not possible to segregate the effects caused by pancreatic cytotoxicity versus those effects stemming from extrapancreatic sites. Moreover, with many rodent models, the presence of phenotypic features from birth makes it difficult to distinguish between developmental effects versus experimentally induced effects. This is particularly true for gene deletion studies, since it is often not possible to differentiate the effects of gene deletion on development from the effects attributable to redundant compensatory mechanisms.

Rodent data also vary markedly due to factors such as species, strain, age, gender, and mode of T2DM induction. The common inbred mouse strains used in T2DM research display considerable strain-dependent variability in whole-body glucose metabolism, such as insulin secretion and action, and counter-regulatory responses. The impact of genetic background on glycemic control has been reported in many studies (Kulkarni et al., 2003; Almind and Kahn, 2004; Berglund et al., 2008), and the susceptibility to diabetes varies among even the most closely related strains such as C57BL/6J and C57BLKS/J (Mu et al., 1999). Gender differences also exist at the species and strain levels to the extent that in some models female disease penetrance is nil. These rodent models also vary in the age of disease onset, disease penetrance, disease severity, and duration of phenotypic manifestations - from the absence of the main T2DM metabolic features such as hyperglycemia and insulin resistance to the presence of only one such feature to reversion of metabolic abnormalities. The loss of phenotype over time also has been reported, for example, in the $\beta$-cell specific insulin receptor knockout models (Kulkarni et al., 2003). Such high variability in the most basic parameters of glucose regulatory mechanisms consequently yields data that are unreliable for humans and also for the Mus and Rattus lineages.

Rodent data extrapolation is further complicated by experimental challenges associated with techniques such as the hyperinsulinemic-euglycemic clamp used for measuring various parameters of glucose regulation in rodents (Ayala et al., 2006). In addition, administration of glucose via the intraperitoneal route averts the incretin response known to potentiate glucose-mediated insulin secretion in humans. Even the techniques utilized for pancreatic imaging cannot be compared directly between rodents and humans. For example, radiolabeled tetrabenazine analogues are used for imaging human 
$\beta$-cell mass, as these ligands selectively bind to the vesicular monoamine transporter 2 (VMAT2) abundantly expressed in human pancreas, but absent in rodent endocrine pancreas (Schafer et al., 2013).

\subsection{Glucose biology: Population and environment level}

It is axiomatic that various environmental factors influence human T2DM development and predisposition. In general, lifestyle choices such as diet and physical activity are superimposed on genetic predisposition and other risk factors. The effect of high-fat diet has been studied extensively in various rodent models of T2DM, but the data have been highly variable. Most rodents tend to become obese on a high fat diet, but there has been considerable variability in weight gain, glucose tolerance, insulin resistance, serum triglycerides, and various other parameters, even among strains (Buettner et al., 2007; Rossmeisl et al., 2003). In addition, regardless of dietary content, some strains have higher fasting plasma glucose levels and lower fasting plasma insulin levels (Andrikopoulos et al., 2005). Changes in dietary composition (fatty acids, carbohydrates, proteins) has also led to considerable variability in rodent studies with some strains being more susceptible to weight gain on a high-fat diet and others on a high-carbohydrate diet (Smith et al., 1997; Warden and Fisler, 2008; Buettner et al., 2006). Some mouse strains are altogether resistant to high-fat diet-induced pathological changes (West et al., 1992). Dietary modifications are often combined with other manipulations, such as gene modifications and chemical inductions, further exacerbating rodent-model variability and correlation with human T2DM pathophysiology. It is clear that for rodents it is not possible to define either an "ideal" high-fat diet or the metabolic perturbations based on dietary composition. Conversely, acute and long-term human studies yield species-specific data indicating that improper diet and sedentary lifestyle contribute to the human metabolic syndrome and T2DM (Wang et al., 2013; Pan et al., 1997; Bienso et al., 2012).

Genetic predisposition is also a risk factor contributing to human T2DM. Human gene linkage analysis, candidate gene approaches, and genome-wide association studies have yielded several single nucleotide polymorphisms (SNP) possibly related to T2DM risk, but they vary greatly among different populations and may not be reproducible or individually significant (Amato et al., 2009). Using information obtained from human linkage analysis to generate transgenic animals has typically not yielded results relevant to humans (Harries et al., 2009). It is evident that no single gene is responsible for a particular phenotype. Rather, the collective actions of multiple genes contribute to the overall pathogenesis of human T2DM. It is interesting that the two most commonly studied geneticderived rodent models of T2DM ( $o b / o b$ and $d b / d b)$, with more than 4,500 publications during the last three decades (Fig. 1), are the models with leptin and leptin receptor mutations. However, leptin or leptin receptor deficiency is rarely associated with human T2DM (Gibson et al., 2004), and it is difficult to derive genetic information relevant to human disease etiopathogenesis from such models.
Epigenetic factors that mediate gene-environment interactions are also important. There are links among diet/nutrients, obesity, energy metabolism, physical activity, and gene expression and regulation such as DNA methylation and histone modifications. For example, genetic background (family history of T2DM) and exercise can alter expression and DNA methylation of several genes involved in skeletal muscle glucose regulation (Nitert et al., 2012). Adding another layer of complication is the recent identification of the effects of regulatory small RNAs and micro RNAs on gene regulation and T2DM complications (Kantharidis et al., 2011). Though humans and rodents have approximately the same number of genes, it is in large part the differences in gene structure and regulation that give rise to two completely different organisms (Dunham et al., 2012). It is also noteworthy that lab animals fed ad libitum are inbred for many generations and thus many genes and phenotypes are enriched for certain traits that may not be relevant to T2DM pathophysiology even for that species or strain. Therefore, data obtained from rodents cannot be extrapolated directly to humans with respect to genetic and epigenetic influences.

Also, rodents housed in controlled environments without exposure to toxins, environmental hazards, and other factors causing cellular stress in humans do not recapitulate the human condition (Murea et al., 2012). The standard laboratory environment also has negative impacts on rodents. Mice are generally housed at $18-22^{\circ} \mathrm{C}$, which is well below their preferred and critical thermoneutrality temperature of $\sim 30^{\circ} \mathrm{C}$ (Gaskill et al., 2012). These suboptimal temperatures exert chronic thermal stress, and rodents try to maintain thermoneutrality by increasing metabolism via increased food intake by as much as 50\% (Lodhi and Semenkovich, 2009; Cannon and Nedergaard, 2011). Even standard control rodents used in research do not serve as appropriate controls since they are "metabolically morbid...sedentary, obese, glucose intolerant, and on a trajectory to premature death" (Martin et al., 2010). These factors have a tremendous potential to skew interspecies extrapolation, particularly in obesity, metabolism, and T2DM fields.

Taken together, data obtained from rodents are affected by many different factors ranging from gene structure to gene expression, organ function to environment. Despite the evolutionarily conserved genes and biochemical pathways humans may have in common with rodents, the cumulative differences and overall integrative physiological processes which account for glucose regulation are markedly different.

\section{T2DM: Bridging the translational gap by "humanizing" research}

Despite the wealth of knowledge regarding mechanisms of glucose regulation in rodents, only a limited number of anti-diabetic drugs are currently available for humans, most of which have little impact on disease progression and outcomes. Erroneous extrapolations from animal models have resulted in poor translational efficacy in the development of effective pharmaceuticals. Perhaps more concerning are serious adverse effects associated with widely used T2DM drugs. Thiazolidinedione 
drugs such as troglitazone, pioglitazone, and rosiglitazone have caused liver disease, myocardial infarctions, and heart failure (Scheen, 2001; Smith, 2003; Taylor and Hobbs, 2009; Nissen and Wolski, 2010). The dipeptidyl peptidase-4 (DPP-4) inhibitor sitagliptin and glucagon-like peptide-1 (GLP-1) mimetics exenatide and liraglutide have been suggested to increase risks for pancreatitis and pancreatic cancer (Elashoff et al., 2011; Butler et al., 2013). These drugs tested safe and effective in rodents, but deleterious consequences resulted in humans. Identifying drug targets and disease mechanisms in rodent models has often prompted researchers to develop treatments based on those optimistic findings, but this may produce effective drugs for humans only if the same targets, mechanisms, and effects are at work in the human disease. Regardless of the method used to induce T2DM-like phenotypes in rodents, it is evident that immutable differences at the molecular and physiological levels of glucose regulation in rodents and humans severely restrict reliable translation. Therefore, future research efforts should focus on increasing the utility of already available methods and the development of new technologies that are more human-based and directly human-relevant. A detailed discussion of this topic is beyond the scope of this review, but a brief discussion follows.

Human-based data can be acquired at various levels ranging from in vitro and in vivo technologies to population studies. In vitro technologies utilizing human heterologous cell lines (e.g., transformed cell lines and human mesenchymal stem cells), human primary cells and tissues (e.g., from biopsies, surgeries, cadavers), and explanted or donated human organs can be used to study various aspects of T2DM ranging from gene expression to organ function. Functional heterologous human $\beta$-cell lines have not been available to researchers to date, but a robust novel technology involving targeted oncogenesis in human fetal tissue holds promise for making functional $\beta$-cell lines as well as other human cell lines from cell types for which cell-specific promoters are readily available (Ravassard et al., 2011). With respect to primary cells, it is important to utilize human primary cells since physiological differences between rodent and human primary cells can interfere with signal transduction and drug responses, as has been reported for primary hepatocytes (Kotokorpi et al., 2007). Using these human cells and tissues, molecular factors involved in signal transduction can be identified with high-throughput microarray techniques (Mei et al., 2010) and signaling pathway protein arrays. Human islets cultured for up to 7 days have been used successfully for high-throughput drug screening (Walpita et al., 2012). Integrating data from multiple sources such as high-density SNP genotyping, microarray data, proteomic and metabolomic data will prove especially useful.

Organotypic 3D cell culture techniques can be adapted to assess biological processes in an environment more consistent with the in vivo environment. For example, upcyte ${ }^{\circledR}$ Hepatocyte $3 \mathrm{D}$ Culture System ${ }^{1}$ offers an environment that mimics the in vivo cellular architecture of the liver (Barrila et al., 2010). Iso- lated primary cells can be used immediately for acute assays or cultured as appropriate for chronic studies. Many aspects of human $\beta$-cell function have already been studied in this manner, as discussed in preceding sections. Using co-culture systems with media-exchange perfusions, interactions among multiple cell types as well as paracrine interactions can be assessed using techniques similar to the "Quasi-Vivo ${ }^{\circledR}$ system" ${ }^{2}$. Events such as paracrine signaling can also be detected in real time using biosensor cells in the vicinity of isolated human islets (Rodriguez-Diaz et al., 2012). Minimally invasive techniques involving phlebotomy and muscle biopsies can be utilized for various biochemical and systemic regulation analyses (Chavez et al., 2009; Zierath et al., 2000), and gene-silencing studies can be extended to human skeletal muscle samples (Austin et al., 2008; Bouzakri and Zierath, 2007).

The use of human organs ex vivo facilitates the integration of cellular data to the organ level. For example, explanted hearts from human patients have been utilized by the Langendorff method to examine electrical activity and contractility, and these data have shown divergence from data obtained in mice (Nanthakumar et al., 2007; Fedorov et al., 2011). Sophisticated organ culture systems like the IdMOC (integrated discrete multiple organ co-culture) allow the researcher to mimic the whole-body systemic interactions affecting various organs as well as paracrine interactions ( $\mathrm{Li}, 2009)$. Emerging tools such as the "organ-on-a-chip" technology can be utilized for further organ-based analyses (disease modeling and drug testing), and will greatly reduce the reliance on animal-based research in the future (Huh et al., 2012; Mowatt, 2012b). Future improvements on such technologies to include "multiple organs-on-a-chip" and "human-on-a-chip" (Mowatt, 2012a) will further facilitate human-based data acquisition.

Whole-animal studies can be done with human subjects using noninvasive or minimally invasive techniques. Positron emission tomography (PET), magnetic resonance imaging (MRI), functional MRI, and advanced ultrasound techniques have emerged as useful noninvasive research methods in recent years. For example, ${ }^{18}$ F-FDG (fluorodeoxyglucose) has been used successfully with PET to study how insulin stimulates glucose uptake in the human liver (Bertoldo et al., 2006; Iozzo et al., 2003; Roden et al., 2001). The ability to monitor glucose and insulin real-time with advanced $\beta$-cell imaging techniques offers valuable insights into human glucose biology (Kilimnik et al., 2011; Ahlgren and Kostromina, 2011). Human epidemiological studies have shown that it is possible to obtain clues to pathological complications in diabetes, for example by measuring retinal vascular caliber from photographs of human retinas (Robinson et al., 2012). Human population studies will likely prove invaluable for identifying T2DM susceptibility genes, for drug testing, and for characterization of other aspects of T2DM such as environmental and lifestyle factors. Evaluation of epigenetic interactions in glucose regulation can also be studied in T2DM patients (Yang et al., 2012; Volkmar et al., 2012).

\footnotetext{
1 http://www.medicyte.com/productsservices/human-upcyte-hepatocytes/3d-cell-culture-kit.html

2 http://kirkstall.org/index.php/quasi-vivo-system/
} 
Integration of information derived from human-based methods can also be facilitated by computational modeling. Systems biology approaches to studying interactions among various biological molecules (and drugs) can be predicted through advanced computer simulations and modeling. For example, Dalla Man et al. (2007) developed an in silico model of the glucoseinsulin system to monitor postprandial glucose regulation. This physiologically based model was generated using quantitative information such as plasma glucose concentration, glucose and insulin fluxes previously obtained from normal and T2DM human subjects, and this guided the development of closed-loop glucose control via implantable insulin pumps. Based on the predictive value of the "artificial pancreas control algorithms" computational model, the FDA approved closed-loop insulin pumps as a substitute for animal testing (Dalla Man et al., 2007; Kovatchev et al., 2009; Patek et al., 2009). This is merely one example that "realistic computer simulation is capable of providing invaluable information about the safety and the limitations of closed-loop control algorithms, guiding clinical studies, and out-ruling ineffective control scenarios in a cost-effective manner" (Kovatchev et al., 2009). Therefore, much effort should be dedicated to developing and using such alternative technologies guided by human-based data acquisition methods.

\section{Human T2DM: What the future holds}

This analysis of rodent model translation in T2DM indicates that cumulative differences from gene expression to cellular signaling to phenotypic expression to environmental impact involved in glucose homeostatic and regulatory characteristics render rodent research results unreliable for human T2DM characterization, prevention, and treatment. While decades of T2DM research efforts have elucidated the details of rodent glucose regulation, the critical knowledge base that is lacking is a detailed understanding of the mechanisms underlying human glucose homeostasis, obesity, insulin resistance, and $\beta$-cell dysfunction as well as their sequelae and responses to interventions in human T2DM.

Incompatible findings from rodent models have raised concerns in other medical fields, including type 1 diabetes, regarding the usefulness of rodent models to study human diseases (Roep et al., 2004; Seok et al., 2012; Mestas and Hughes, 2004; Demetrius, 2005). Researchers are now questioning the validity of rodent models to study human glucose biology, with many lamenting that "clinical investigations have fallen out of favor with funding agencies and with reviewers and scientists" and that "[w]e need to refocus and adapt new methodologies for use in humans to understand disease biology in humans"(Caicedo, 2012; Bell, 2013; McManus, 2013). However, "[the] rodent islet model is so ingrained that there is a reluctance to view discrepant findings as real differences" (Caicedo, 2012). With the T2DM epidemic at hand, it is vital to consider whether rodent models provide reliable, reproducible, and translatable insights into human T2DM mechanisms and therapeutics.

Research and clinical advances in the field of T2DM require a paradigm shift, focusing on the use of human-based methods that can greatly improve bench-to-bedside success. Decades of research have made it clear why a priori application of rodent data to humans is inappropriate and why human-based data must go from being anecdotal to systematic frontline evidence. Therefore, scientists and funding agencies should prioritize human-based strategies to study human T2DM characteristics and therapeutic options. This is the clear path to deal with the global epidemic of T2DM.

\section{References}

Abdul-Ghani, M. A. and DeFronzo, R. A. (2010). Pathogenesis of insulin resistance in skeletal muscle. J Biomed Biotechnol 2010, 476279. http://dx.doi.org/10.1155/2010/476279

ADA - American Diabetes Association (2012). Diagnosis and classification of diabetes mellitus. Diabetes Care 35, Suppl 1, S64-71. http://dx.doi.org/10.2337/dc12-s064

Ahlgren, U. and Kostromina, E. (2011). Imaging the pancreatic beta cell. In D. Wagner (eds.), Type 1 Diabetes - Pathogenesis, Genetics and Immunotherapy. InTech. http://dx.doi. org/10.5772/22739

Ahren, B. (2000). Autonomic regulation of islet hormone secretion - implications for health and disease. Diabetologia 43, 393-410. http://dx.doi.org/10.1007/s001250051322

Almind, K. and Kahn, C. R. (2004). Genetic determinants of energy expenditure and insulin resistance in diet-induced obesity in mice. Diabetes 53, 3274-3285. http://dx.doi.org/10.2337/ diabetes.53.12.3274

Amato, R., Pinelli, M., Monticelli, A., et al. (2009). Genomewide scan for signatures of human population differentiation and their relationship with natural selection, functional pathways and diseases. PLoS One 4, e7927. http://dx.doi. org/10.1371/journal.pone.0007927

Andrikopoulos, S., Massa, C. M., Aston-Mourney, K., et al. (2005). Differential effect of inbred mouse strain (C57BL/6, $\mathrm{DBA} / 2,129 \mathrm{~T} 2)$ on insulin secretory function in response to a high fat diet. $J$ Endocrinol 187, 45-53. http://dx.doi. org/10.1677/joe.1.06333

Artner, I., Hang, Y., Mazur, M., et al. (2010). MafA and MafB regulate genes critical to beta-cells in a unique temporal manner. Diabetes 59, 2530-2539. http://dx.doi.org/10.2337/db100190

Austin, R. L., Rune, A., Bouzakri, K., et al. (2008). siRNAmediated reduction of inhibitor of nuclear factor-kappaB kinase prevents tumor necrosis factor-alpha-induced insulin resistance in human skeletal muscle. Diabetes 57, 2066-2073. http://dx.doi.org/10.2337/db07-0763

Ayala, J. E., Bracy, D. P., McGuinness, O. P., et al. (2006). Considerations in the design of hyperinsulinemic-euglycemic clamps in the conscious mouse. Diabetes 55, 390-397. http:// dx.doi.org/10.2337/diabetes.55.02.06.db05-0686

Babaya, N., Nakayama, M., Moriyama, H., et al. (2006). A new model of insulin-deficient diabetes: male NOD mice with a single copy of Ins1 and no Ins2. Diabetologia 49, 1222-1228. http://dx.doi.org/10.1007/s00125-006-0241-4

Baetens, D., Malaisse-Lagae, F., Perrelet, A., et al. (1979). Endocrine pancreas: three-dimensional reconstruction shows 
two types of islets of langerhans. Science 206, 1323-1325. http://dx.doi.org/10.1126/science.390711

Barrila, J., Radtke, A. L., Crabbe, A., et al. (2010). Organotypic 3D cell culture models: using the rotating wall vessel to study host-pathogen interactions. Nat Rev Microbiol 8, 791-801. http://dx.doi.org/10.1038/nrmicro2423

Belke, D. D., Swanson, E. A., and Dillmann, W. H. (2004). Decreased sarcoplasmic reticulum activity and contractility in diabetic db/db mouse heart. Diabetes 53, 3201-3208. http:// dx.doi.org/10.2337/diabetes.53.12.3201

Bell, G. I., Burant, C. F., Takeda, J., et al. (1993). Structure and function of mammalian facilitative sugar transporters. J Biol Chem 268, 19161-19164. http://www.jbc.org/con tent/268/26/19161.long

Bell, G. I. (2013). Banting medal for scientific achievement award lecture - Genetics of diabetes - A personal journey of discovery. http://bit.ly/1eKryAn

Bennett, B. D., Jetton, T. L., Ying, G., et al. (1996). Quantitative subcellular imaging of glucose metabolism within intact pancreatic islets. J Biol Chem 271, 3647-3651. http://dx.doi. org/10.1074/jbc.271.7.3647

Berglund, E. D., Li, C. Y., Poffenberger, G., et al. (2008). Glucose metabolism in vivo in four commonly used inbred mouse strains. Diabetes 57, 1790-1799. http://dx.doi.org/10.2337/ $\mathrm{db} 07-1615$

Berglund, O. (1980). Different dynamics of insulin secretion in the perfused pancreas of mouse and rat. Acta Endocrinol ( $\mathrm{Co}$ penh) 93, 54-60. http://dx.doi.org/10.1530/acta.0.0930054

Berglund, O. (1987). Lack of glucose-induced priming of insulin release in the perfused mouse pancreas. J Endocrinol 114, 185-189. http://dx.doi.org/10.1677/joe.0.1140185

Bertoldo, A., Pencek, R. R., Azuma, K., et al. (2006). Interactions between delivery, transport, and phosphorylation of glucose in governing uptake into human skeletal muscle. Diabetes 55, 3028-3037. http://dx.doi.org/10.2337/db06-0762

Bienso, R. S., Ringholm, S., Kiilerich, K., et al. (2012). GLUT4 and glycogen synthase are key players in bed rest-induced insulin resistance. Diabetes 61, 1090-1099. http://dx.doi. org/10.2337/db11-0884

Boam, D. S., Clark, A. R., and Docherty, K. (1990). Positive and negative regulation of the human insulin gene by multiple trans-acting factors. J Biol Chem 265, 8285-8296. http:// www.jbc.org/content $/ 265 / 14 / 8285$.long

Bonner-Weir, S. and Orci, L. (1982). New perspectives on the microvasculature of the islets of Langerhans in the rat. Diabetes 31, 883-889. http://dx.doi.org/10.2337/diab.31.10.883

Bosco, D., Armanet, M., Morel, P., et al. (2010). Unique arrangement of alpha- and beta-cells in human islets of Langerhans. Diabetes 59, 1202-1210. http://dx.doi.org/10.2337/ db09-1177

Bouche, C., Serdy, S., Kahn, C. R., et al. (2004). The cellular fate of glucose and its relevance in type 2 diabetes. Endocr Rev 25, 807-830. http://dx.doi.org/10.1210/er.2003-0026

Bouzakri, K. and Zierath, J. R. (2007). MAP4K4 gene silencing in human skeletal muscle prevents tumor necrosis factor-alpha-induced insulin resistance. J Biol Chem 282, 7783-7789. http://dx.doi.org/10.1074/jbc.M608602200
Braun, M., Ramracheya, R., Bengtsson, M., et al. (2008). Voltage-gated ion channels in human pancreatic beta-cells: electrophysiological characterization and role in insulin secretion. Diabetes 57, 1618-1628. http://dx.doi.org/10.2337/ db07-0991

Brissova, M., Fowler, M. J., Nicholson, W. E., et al. (2005). Assessment of human pancreatic islet architecture and composition by laser scanning confocal microscopy. J Histochem Cytochem 53, 1087-1097. http://dx.doi.org/10.1369/ jhc.5C6684.2005

Brodsky, F. M. (2012). Diversity of clathrin function: new tricks for an old protein. Аnпи Rev Cell Dev Biol 28, 309-336. http:// dx.doi.org/10.1146/annurev-cellbio-101011-155716

Bruning, J. C., Michael, M. D., Winnay, J. N., et al. (1998). A muscle-specific insulin receptor knockout exhibits features of the metabolic syndrome of NIDDM without altering glucose tolerance. Mol Cell 2, 559-569. http://dx.doi.org/10.1016/ S1097-2765(00)80155-0

Buettner, R., Parhofer, K. G., Woenckhaus, M., et al. (2006). Defining high-fat-diet rat models: metabolic and molecular effects of different fat types. J Mol Endocrinol 36, 485-501. http://dx.doi.org/10.1677/jme.1.01909

Buettner, R., Scholmerich, J., and Bollheimer, L. C. (2007). High-fat diets: modeling the metabolic disorders of human obesity in rodents. Obesity (Silver Spring) 15, 798-808. http:// dx.doi.org/10.1038/oby.2007.608

Butler, A. E., Janson, J., Bonner-Weir, S., et al. (2003). Beta-cell deficit and increased beta-cell apoptosis in humans with type 2 diabetes. Diabetes 52, 102-110. http://dx.doi.org/10.2337/ diabetes.52.1.102

Butler, A. E., Campbell-Thompson, M., Gurlo, T., et al. (2013). Marked expansion of exocrine and endocrine pancreas with incretin therapy in humans with increased exocrine pancreas dysplasia and the potential for glucagon-producing neuroendocrine tumors. Diabetes 62, 2595-2604. http://dx.doi. org $/ 10.2337 / \mathrm{db} 12-1686$

Cabrera, O., Berman, D. M., Kenyon, N. S., et al. (2006). The unique cytoarchitecture of human pancreatic islets has implications for islet cell function. Proc Natl Acad Sci U S A 103, 2334-2339. http://dx.doi.org/10.1073/pnas.0510790103

Caicedo, A. (2012). Paracrine and autocrine interactions in the human islet: more than meets the eye. Semin Cell Dev Biol 24, 11-21. http://dx.doi.org/10.1016/j.semcdb.2012.09.007

Cannon, B. and Nedergaard, J. (2011). Nonshivering thermogenesis and its adequate measurement in metabolic studies. $J$ Exp Biol 214, 242-253. http://dx.doi.org/10.1242/jeb.050989

CDC - Centers for Disease Control and Prevention (2011). National diabetes fact sheet. http://bit.ly/1jJ5U1w

Chatzigeorgiou, A., Halapas, A., Kalafatakis, K., et al. (2009). The use of animal models in the study of diabetes mellitus. In Vivo 23, 245-258.

Chavez, A. O., Molina-Carrion, M., Abdul-Ghani, M. A., et al. (2009). Circulating fibroblast growth factor-21 is elevated in impaired glucose tolerance and type 2 diabetes and correlates with muscle and hepatic insulin resistance. Diabetes Care 32, 1542-1546. http://dx.doi.org/10.2337/dc09-0684

Cline, G. W., Petersen, K. F., Krssak, M., et al. (1999). Im- 
paired glucose transport as a cause of decreased insulinstimulated muscle glycogen synthesis in type 2 diabetes. $N$ Engl J Med 341, 240-246. http://dx.doi.org/10.1056/ NEJM199907223410404

Coleman, R., Hayek, T., Keidar, S., et al. (2006). A mouse model for human atherosclerosis: long-term histopathological study of lesion development in the aortic arch of apolipoprotein E-deficient (E0) mice. Acta Histochem 108, 415-424. http:// dx.doi.org/10.1016/j.acthis.2006.07.002

Cordell, B., Diamond, D., Smith, S., et al. (1982). Disproportionate expression of the two nonallelic rat insulin genes in a pancreatic tumor is due to translational control. Cell 31,531542. http://dx.doi.org/10.1016/0092-8674(82)90309-9

Dai, C., Brissova, M., Hang, Y., et al. (2012). Islet-enriched gene expression and glucose-induced insulin secretion in human and mouse islets. Diabetologia 55, 707-718. http:// dx.doi.org/10.1007/s00125-011-2369-0

Dalla Man, C., Rizza, R. A., and Cobelli, C. (2007). Meal simulation model of the glucose-insulin system. IEEE Trans Biomed Eng 54, 1740-1749. http://dx.doi.org/10.1109/ TBME.2007.893506

Daniels, A., Linz, D., van Bilsen, M., et al. (2012). Long-term severe diabetes only leads to mild cardiac diastolic dysfunction in Zucker diabetic fatty rats. Eur J Heart Fail 14, 193201. http://dx.doi.org/10.1093/eurjhf/hfr166

Davies, P. O., Poirier, C., Deltour, L., et al. (1994). Genetic reassignment of the insulin-1 (Ins1) gene to distal mouse chromosome 19. Genomics 21, 665-667. http://dx.doi.org/10.1006/ geno.1994.1334

De Vos, A., Heimberg, H., Quartier, E., et al. (1995). Human and rat beta cells differ in glucose transporter but not in glucokinase gene expression. J Clin Invest 96, 2489-2495. http:// dx.doi.org/10.1172/JCI118308

DeFronzo, R. A. and Tripathy, D. (2009). Skeletal muscle insulin resistance is the primary defect in type 2 diabetes. Diabetes Care 32, Suppl 2, S157-163. http://dx.doi.org/10.2337/ dc09-S302

Del Prato, S., Leonetti, F., Simonson, D. C., et al. (1994). Effect of sustained physiologic hyperinsulinaemia and hyperglycaemia on insulin secretion and insulin sensitivity in man. Diabetologia 37, 1025-1035. http://dx.doi.org/10.1007/ BF00400466

Del Prato, S. (2003). Loss of early insulin secretion leads to postprandial hyperglycaemia. Diabetologia 46, Suppl 1, M2-8.

Demetrius, L. (2005). Of mice and men. When it comes to studying ageing and the means to slow it down, mice are not just small humans. EMBO Rep 6, Spec No, S39-44. http://dx.doi. org/10.1038/sj.embor.7400422

Denton, J. S. and Jacobson, D. A. (2012). Channeling dysglycemia: ion-channel variations perturbing glucose homeostasis. Trends Endocrinol Metab 23, 41-48. http://dx.doi. org/10.1016/j.tem.2011.09.004

Desvergne, B., Michalik, L., and Wahli, W. (2006). Transcriptional regulation of metabolism. Physiol Rev 86, 465-514. http://dx.doi.org/10.1152/physrev.00025.2005

Dib-Hajj, S. D., Yang, Y., Black, J. A., et al. (2013). The $\mathrm{Na}(\mathrm{V}) 1.7$ sodium channel: from molecule to man. Nat Rev
Neurosci 14, 49-62. http://dx.doi.org/10.1038/nrn3404

Dorrell, C., Schug, J., Lin, C. F., et al. (2011). Transcriptomes of the major human pancreatic cell types. Diabetologia 54, 2832-2844. http://dx.doi.org/10.1007/s00125-011-2283-5

Dunham, I., Kundaje, A., Aldred, S. F., et al. (2012). An integrated encyclopedia of DNA elements in the human genome. Nature 489, 57-74. http://dx.doi.org/10.1038/nature11247

Eizirik, D. L., Korbutt, G. S., and Hellerstrom, C. (1992). Prolonged exposure of human pancreatic islets to high glucose concentrations in vitro impairs the beta-cell function. J Clin Invest 90, 1263-1268. http://dx.doi.org/10.1172/JCI115989

Elashoff, M., Matveyenko, A. V., Gier, B., et al. (2011). Pancreatitis, pancreatic, and thyroid cancer with glucagon-like peptide-1-based therapies. Gastroenterology 141, 150-156. http://dx.doi.org/10.1053/j.gastro.2011.02.018

Fam, B. C., Rose, L. J., Sgambellone, R., et al. (2012). Normal muscle glucose uptake in mice deficient in muscle GLUT4. $J$ Endocrinol 214, 313-327. http://dx.doi.org/10.1530/JOE-120032

Farret, A., Vignaud, M., Dietz, S., et al. (2004). P2Y purinergic potentiation of glucose-induced insulin secretion and pancreatic beta-cell metabolism. Diabetes 53, Suppl 3, S63-66. http://dx.doi.org/10.2337/diabetes.53.suppl_3.S63

Fedorov, V. V., Glukhov, A. V., Ambrosi, C. M., et al. (2011). Effects of KATP channel openers diazoxide and pinacidil in coronary-perfused atria and ventricles from failing and nonfailing human hearts. J Mol Cell Cardiol 51, 215-225. http:// dx.doi.org/10.1016/j.yjmcc.2011.04.016

Ferrer, J., Benito, C., and Gomis, R. (1995). Pancreatic islet GLUT2 glucose transporter mRNA and protein expression in humans with and without NIDDM. Diabetes 44, 1369-1374. http://dx.doi.org/10.2337/diab.44.12.1369

Fiaschi-Taesch, N., Bigatel, T. A., Sicari, B., et al. (2009). Survey of the human pancreatic beta-cell G1/S proteome reveals a potential therapeutic role for cdk- 6 and cyclin D1 in enhancing human beta-cell replication and function in vivo. Diabetes 58, 882-893. http://dx.doi.org/10.2337/db08-0631

Fiaschi-Taesch, N. M., Salim, F., Kleinberger, J., et al. (2010). Induction of human beta-cell proliferation and engraftment using a single $\mathrm{G} 1 / \mathrm{S}$ regulatory molecule, cdk6. Diabetes 59 , 1926-1936. http://dx.doi.org/10.2337/db09-1776

Forbes, J. M. and Cooper, M. E. (2013). Mechanisms of diabetic complications. Physiol Rev 93, 137-188. http://dx.doi. org/10.1152/physrev.00045.2011

Galman, C., Matasconi, M., Persson, L., et al. (2007). Age-induced hypercholesterolemia in the rat relates to reduced elimination but not increased intestinal absorption of cholesterol. Am J Physiol Endocrinol Metab 293, E737-742. http://dx.doi. org/10.1152/ajpendo.00166.2007

Gaskill, B. N., Gordon, C. J., Pajor, E. A., et al. (2012). Heat or insulation: behavioral titration of mouse preference for warmth or access to a nest. PLoS One 7, e32799. http://dx.doi. org/10.1371/journal.pone.0032799

Gautam, D., Han, S. J., Duttaroy, A., et al. (2007). Role of the M3 muscarinic acetylcholine receptor in beta-cell function and glucose homeostasis. Diabetes Obes Metab 9, Suppl 2, 158-169. http://dx.doi.org/10.1111/j.1463-1326.2007.00781 
Gibson, W. T., Farooqi, I. S., Moreau, M., et al. (2004). Congenital leptin deficiency due to homozygosity for the Delta133G mutation: report of another case and evaluation of response to four years of leptin therapy. J Clin Endocrinol Metab 89, 4821-4826. http://dx.doi.org/10.1210/jc.2004-0376

Gilon, P. and Henquin, J. C. (2001). Mechanisms and physiological significance of the cholinergic control of pancreatic beta-cell function. Endocr Rev 22, 565-604. http://dx.doi. org/10.1210/edrv.22.5.0440

Grodsky, G. M. (1989). A new phase of insulin secretion. How will it contribute to our understanding of beta-cell function? Diabetes 38, 673-678. http://dx.doi.org/10.2337/diab.38.6.673

Gromada, J., Franklin, I., and Wollheim, C. B. (2007). Alphacells of the endocrine pancreas: 35 years of research but the enigma remains. Endocr Rev 28, 84-116. http://dx.doi. org/10.1210/er.2006-0007

Guillam, M. T., Hummler, E., Schaerer, E., et al. (1997). Early diabetes and abnormal postnatal pancreatic islet development in mice lacking Glut-2. Nat Genet 17,327-330. http://dx.doi. org/10.1038/ng1197-327

Guo, S., Vanderford, N. L., and Stein, R. (2010). Phosphorylation within the MafA $\mathrm{N}$ terminus regulates $\mathrm{C}$-terminal dimerization and DNA binding. J Biol Chem 285, 12655-12661. http://dx.doi.org/10.1074/jbc.M110.105759

Haataja, L., Gurlo, T., Huang, C. J., et al. (2008). Islet amyloid in type 2 diabetes, and the toxic oligomer hypothesis. Endocr Rev 29, 303-316. http://dx.doi.org/10.1210/er.2007-0037

Hang, Y. and Stein, R. (2011). MafA and MafB activity in pancreatic beta cells. Trends Endocrinol Metab 22, 364-373. http://dx.doi.org/10.1016/j.tem.2011.05.003

Hansen, P. A., Han, D. H., Marshall, B. A., et al. (1998). A high fat diet impairs stimulation of glucose transport in muscle. Functional evaluation of potential mechanisms. J Biol Chem 273, 26157-26163. http://dx.doi.org/10.1074/jbc.273.40.26157

Harries, L. W., Brown, J. E., and Gloyn, A. L. (2009). Species-specific differences in the expression of the HNF1A, HNF1B and HNF4A genes. PLoS One 4, e7855. http://dx.doi. org/10.1371/journal.pone.0007855

Hay, C. W. and Docherty, K. (2006). Comparative analysis of insulin gene promoters: implications for diabetes research. Diabetes 55, 3201-3213. http://dx.doi.org/10.2337/db06-0788

Hicks, K. K., Seifen, E., Stimers, J. R., et al. (1998). Effects of streptozotocin-induced diabetes on heart rate, blood pressure and cardiac autonomic nervous control. J Auton Nerv Syst 69, 21-30. http://dx .doi.org/10.1016/S0165-1838(98)00004-6

Huh, D., Leslie, D. C., Matthews, B. D., et al. (2012). A human disease model of drug toxicity-induced pulmonary edema in a lung-on-a-chip microdevice. Sci Transl Med 4, 159ra147. http://dx.doi.org/10.1126/scitranslmed.3004249

Iglesias, A., Murga, M., Laresgoiti, U., et al. (2004). Diabetes and exocrine pancreatic insufficiency in E2F1/E2F2 doublemutant mice. J Clin Invest 113, 1398-1407.

Iozzo, P., Geisler, F., Oikonen, V., et al. (2003). Insulin stimulates liver glucose uptake in humans: an 18F-FDG PET Study. J Nucl Med 44, 682-689. http://dx.doi.org/10.1172/ JCI200418879
Ishibashi, S., Goldstein, J. L., Brown, M. S., et al. (1994). Massive xanthomatosis and atherosclerosis in cholesterol-fed low density lipoprotein receptor-negative mice. J Clin Invest 93, 1885-1893. http://dx.doi.org/10.1172/JCI117179

Ishida, B. Y., Blanche, P. J., Nichols, A. V., et al. (1991). Effects of atherogenic diet consumption on lipoproteins in mouse strains C57BL/6 and C3H. J Lipid Res 32, 559-568. http:// www.jlr.org/content/32/4/559.long

Islam, M. S. and Loots du, T. (2009). Experimental rodent models of type 2 diabetes: a review. Methods Find Exp Clin Pharmacol 31, 249-261. http://dx.doi.org/10.1358/ mf.2009.31.4.1362513

Ivy, J. L. (1999). Role of carbohydrate in physical activity. Clin Sports Med 18, 469-484, http://dx.doi.org/10.1016/S02785919(05)70162-9

Jacques-Silva, M. C., Correa-Medina, M., Cabrera, O., et al. (2010). ATP-gated P2X3 receptors constitute a positive autocrine signal for insulin release in the human pancreatic beta cell. Proc Natl Acad Sci U S A 107, 6465-6470. http://dx.doi. org/10.1073/pnas.0908935107

Janke, J., Engeli, S., Boschmann, M., et al. (2006). Retinolbinding protein 4 in human obesity. Diabetes 55, 2805-2810. http://dx.doi.org/10.2337/db06-0616

Jensen, T.E. and Richter, E. A. (2012). Regulation of glucose and glycogen metabolism during and after exercise. J Physiol 590, 1069-1076. http://dx.doi.org/10.1113/jphysiol.2011.224972

Jiao, S., Cole, T. G., Kitchens, R. T., et al. (1990). Genetic heterogeneity of plasma lipoproteins in the mouse: control of low density lipoprotein particle sizes by genetic factors. $J$ Lipid Res 31, 467-477. http://www.jlr.org/content/31/3/467.long

Jing, X., Li, D. Q., Olofsson, C. S., et al. (2005). CaV2.3 calcium channels control second-phase insulin release. J Clin Invest 115, 146-154. http://dx.doi.org/10.1172/JCI200522518

Johnson, J. D., Kuang, S., Misler, S., et al. (2004). Ryanodine receptors in human pancreatic beta cells: localization and effects on insulin secretion. Faseb J 18, 878-880. http://www. fasebj.org/content/early/2004/04/30/fj.03-1280fje.long

Johnson, J. H., Ogawa, A., Chen, L., et al. (1990). Underexpression of beta cell high $\mathrm{Km}$ glucose transporters in noninsulin-dependent diabetes. Science 250, 546-549. http://dx.doi. org/10.1126/science.2237405

Jonas, J. C., Gilon, P., and Henquin, J. C. (1998). Temporal and quantitative correlations between insulin secretion and stably elevated or oscillatory cytoplasmic $\mathrm{Ca}^{2+}$ in mouse pancreatic beta-cells. Diabetes 47, 1266-1273. http://diabetes.diabetesjournals.org/content/47/8/1266.long

Kahn, S. E., Hull, R. L., and Utzschneider, K. M. (2006). Mechanisms linking obesity to insulin resistance and type 2 diabetes. Nature 444, 840-846. http://dx.doi.org/10.1038/nature05482

Kakita, K., Giddings, S., and Permutt, M. A. (1982). Biosynthesis of rat insulins I and II: evidence for differential expression of the two genes. Proc Natl Acad Sci U S A 79, 2803-2807. http://dx.doi.org/10.1073/pnas.79.9.2803

Kantharidis, P., Wang, B., Carew, R. M., et al. (2011). Diabetes complications: the microRNA perspective. Diabetes 60 , 1832-1837. http://dx.doi.org/10.2337/db11-0082 
Kasuga, M., Ogawa, W., and Ohara, T. (2003). Tissue glycogen content and glucose intolerance. J Clin Invest 111, 1282-1284. http://dx.doi.org/10.1172/JCI200318526

Katz, E. B., Stenbit, A. E., Hatton, K., et al. (1995). Cardiac and adipose tissue abnormalities but not diabetes in mice deficient in GLUT4. Nature 377, 151-155. http://dx.doi. org/10.1038/377151a0

Kedra, D., Peyrard, M., Fransson, I., et al. (1996). Characterization of a second human clathrin heavy chain polypeptide gene (CLH-22) from chromosome 22q11. Hum Mol Genet 5, 625631. http://dx.doi.org/10.1093/hmg/5.5.625

Kilimnik, G., Zhao, B., Jo, J., et al. (2011). Altered islet composition and disproportionate loss of large islets in patients with type 2 diabetes. PLoS One 6, e27445. http://dx.doi. org/10.1371/journal.pone.0027445

Kim, A., Miller, K., Jo, J., et al . (2009). Islet architecture: A comparative study. Islets 1, 129-136. http://dx.doi.org/10.4161/ isl.1.2.9480

King, P. A., Horton, E. D., Hirshman, M. F., et al. (1992). Insulin resistance in obese Zucker rat (fa/fa) skeletal muscle is associated with a failure of glucose transporter translocation. J Clin Invest 90, 1568-1575. http://dx.doi.org/10.1172/ JCI116025

Klein, D., Misawa, R., Bravo-Egana, V., et al. (2013). MicroRNA expression in alpha and beta cells of human pancreatic islets. PLoS One 8, e55064. http://dx.doi.org/10.1371/journal. pone.0055064

Koistinen, H. A. and Zierath, J. R. (2002). Regulation of glucose transport in human skeletal muscle. Ann Med 34, 410418. http://dx.doi.org/10.1080/078538902321012351

Kotokorpi, P., Ellis, E., Parini, P., et al. (2007). Physiological differences between human and rat primary hepatocytes in response to liver $\mathrm{X}$ receptor activation by 3-[3-[N-(2-chloro-3trifluoromethylbenzyl)-(2,2-diphenylethyl)amino]propyloxy] phe nylacetic acid hydrochloride (GW3965). Mol Pharmacol 72, 947-955. http://dx.doi.org/10.1124/mol.107.037358

Kovatchev, B. P., Breton, M., Man, C. D., et al. (2009). In silico preclinical trials: a proof of concept in closed-loop control of type 1 diabetes. J Diabetes Sci Technol 3, 44-55. http://dx.doi. org/10.1177/193229680900300106

Ku, S. K., Lee, H. S., and Lee, J. H. (2002). An immunohistochemical study on the pancreatic endocrine cells of the C57BL/6 mouse. J Vet Sci 3, 327-333. http://www.vetsci.org/ paper/journal_view.html?year $=2002 \&$ vol $=3 \&$ iss $=4 \&$ page $=3$ 27

Kubota, N., Kubota, T., Itoh, S., et al. (2008). Dynamic functional relay between insulin receptor substrate 1 and 2 in hepatic insulin signaling during fasting and feeding. Cell Metab 8, 49-64. http://dx.doi.org/10.1016/j.cmet.2008.05.007

Kulkarni, R. N., Almind, K., Goren, H. J., et al. (2003). Impact of genetic background on development of hyperinsulinemia and diabetes in insulin receptor/insulin receptor substrate-1 double heterozygous mice. Diabetes 52, 1528-1534. http:// dx.doi.org/10.2337/diabetes.52.6.1528

Lenzen, S. (1979). Insulin secretion by isolated perfused rat and mouse pancreas. Am J Physiol 236, E391-400. http://ajpendo. physiology.org/content/236/4/E391
Lenzen, S. (2008). The mechanisms of alloxan- and streptozotocin-induced diabetes. Diabetologia 51, 216-226. http:// dx.doi.org/10.1007/s00125-007-0886-7

Leon, C., Freund, M., Latchoumanin, O., et al. (2005). The $\mathrm{P} 2 \mathrm{Y}(1)$ receptor is involved in the maintenance of glucose homeostasis and in insulin secretion in mice. Purinergic Signal 1, 145-151. http://dx.doi.org/10.1007/s11302-005-6209-x

Li, A. P. (2009). The use of the Integrated discrete Multiple Organ Co-culture (IdMOC) system for the evaluation of multiple organ toxicity. Altern Lab Anim 37, 377-385. http://www. frame.org.uk/atla_article.php?art_id $=1188 \&$ abstract $=$ true

Lin, C. C., Chen, Y. J., Chen, C. Y., et al. (2012). Crosstalk between transcription factors and microRNAs in human protein interaction network. BMC Syst Biol 6, 18. http://dx.doi. org/10.1186/1752-0509-6-18

Lindroos, J., Husa, J., Mitterer, G., et al. (2013). Human but not mouse adipogenesis is critically dependent on LMO3. Cell Metab 18, 62-74. http://dx.doi.org/10.1016/j.cmet.2013.05.020

Liu, Y. J., Cheng, H., Drought, H., et al. (2003). Activation of the KATP channel-independent signaling pathway by the nonhydrolyzable analog of leucine, BCH. Am J Physiol Endocrinol Metab 285, E380-389. http://dx.doi.org/10.1152/ ajpendo.00008.2003

Lodhi, I. J. and Semenkovich, C. F. (2009). Why we should put clothes on mice. Cell Metab 9, 111-112. http://dx.doi. org/10.1016/j.cmet.2009.01.004

Lomedico, P., Rosenthal, N., Efstratidadis, A., et al. (1979). The structure and evolution of the two nonallelic rat preproinsulin genes. Cell 18, 545-558. http://dx.doi.org/10.1016/00928674(79)90071-0

Lukinius, A., Wilander, E., Westermark, G. T., et al. (1989). Colocalization of islet amyloid polypeptide and insulin in the B cell secretory granules of the human pancreatic islets. Diabetologia 32, 240-244. http://dx.doi.org/10.1007/BF00285291

Lutz, T. A. and Woods, S. C. (2012). Overview of animal models of obesity. Curr Protoc Pharmacol, Chapter 5, Unit 5.61. http://dx.doi.org/10.1002/0471141755.ph0561s58

Ma, Y. H., Wang, J., Rodd, G. G., et al. (1995). Differences in insulin secretion between the rat and mouse: role of cAMP. Eur J Endocrinol 132, 370-376. http://dx.doi.org/10.1530/ eje. 0.1320370

MacDonald, M. J. (2002). Differences between mouse and rat pancreatic islets: succinate responsiveness, malic enzyme, and anaplerosis. Am J Physiol Endocrinol Metab 283, E302310. http://dx.doi.org/10.1152/ajpendo.00041.2002

MacDonald, M. J., Longacre, M. J., Stoker, S. W., et al. (2011). Differences between human and rodent pancreatic islets: low pyruvate carboxylase, atp citrate lyase, and pyruvate carboxylation and high glucose-stimulated acetoacetate in human pancreatic islets. J Biol Chem 286, 18383-18396. http:// dx.doi.org/10.1074/jbc.M111.241182

Macfarlane, W. M., Shepherd, R. M., Cosgrove, K. E., et al. (2000). Glucose modulation of insulin mRNA levels is dependent on transcription factor PDX-1 and occurs independently of changes in intracellular $\mathrm{Ca}^{2+}$. Diabetes $49,418-423$. http://dx.doi.org/10.2337/diabetes.49.3.418

Martin, B., Ji, S., Maudsley, S., et al. (2010). "Control” labo- 
ratory rodents are metabolically morbid: why it matters. Proc Natl Acad Sci U S A 107, 6127-6133. http://dx.doi. org/10.1073/pnas.0912955107

Maston, G. A., Evans, S. K., and Green, M. R. (2006). Transcriptional regulatory elements in the human genome. Annu Rev Genomics Hum Genet 7, 29-59. http://dx .doi.org/10.1146/ annurev.genom.7.080505.115623

Matveyenko, A. V. and Butler, P. C. (2006). Islet amyloid polypeptide (IAPP) transgenic rodents as models for type 2 diabetes. Ilar J 47, 225-233. http://dx.doi.org/10.1093/ ilar.47.3.225

Mauvais-Jarvis, F., Clegg, D. J., and Hevener, A. L. (2013). The Role of Estrogens in Control of Energy Balance and Glucose Homeostasis. Endocr Rev 34, 309-338. http://dx.doi. org/10.1210/er.2012-1055

McCulloch, L. J., van de Bunt, M., Braun, M., et al. (2011). GLUT2 (SLC2A2) is not the principal glucose transporter in human pancreatic beta cells: implications for understanding genetic association signals at this locus. Mol Genet Metab 104, 648-653. http://dx.doi.org/10.1016/j.ymgme.2011.08.026

McManus, R. (2013). Ex-director Zerhouni surveys value of NIH research. http://nihrecord.od.nih.gov/ newsletters/2013/06_21_2013/story1.htm

Mestas, J. and Hughes, C. C. (2004). Of mice and not men: differences between mouse and human immunology. J Immunol 172, 2731-2738. http://www.jimmunol.org/ content/172/5/2731.long

Mei, Y., Hollister-Lock, J., Bogatyrev, S. R., et al. (2010). A high throughput micro-array system of polymer surfaces for the manipulation of primary pancreatic islet cells. Biomaterials 31, 8989-8995. http://dx.doi.org/10.1016/j.bio materials.2010.08.029

Mendel, D. B., Hansen, L. P., Graves, M. K., et al. (1991). HNF-1 alpha and HNF-1 beta (vHNF-1) share dimerization and homeo domains, but not activation domains, and form heterodimers in vitro. Genes Dev 5, 1042-1056. http://dx.doi. org/10.1101/gad.5.6.1042

Michael, M. D., Kulkarni, R. N., Postic, C., et al. (2000). Loss of insulin signaling in hepatocytes leads to severe insulin resistance and progressive hepatic dysfunction. Mol Cell 6, 8797. http://dx.doi.org/10.1016/S1097-2765(05)00015-8

Miki, T., Nagashima, K., Tashiro, F., et al. (1998). Defective insulin secretion and enhanced insulin action in KATP channeldeficient mice. Proc Natl Acad Sci U S A 95, 10402-10406. http://dx.doi.org/10.1073/pnas.95.18.10402

Mikkelsen, T. S., Xu, Z., Zhang, X., et al. (2010). Comparative epigenomic analysis of murine and human adipogenesis. Cell 143, 156-169. http://dx.doi.org/10.1016/j.cell.2010.09.006

Mowatt, T. (2012a). Wyss Institute to receive up to $\$ 37$ million from DARPA to integrate multiple organ-on-chip systems to mimic the whole human body. http://wyss.harvard.edu/view pressrelease/91/

Mowatt, T. (2012b). Harvard's Wyss Institute creates living human gut-on-a-chip. http://wyss.harvard.edu/viewpressre lease/80/

Mu, J. L., Naggert, J. K., Svenson, K. L., et al. (1999). Quantitative trait loci analysis for the differences in susceptibility to atherosclerosis and diabetes between inbred mouse strains C57BL/6J and C57BLKS/J. J Lipid Res 40, 1328-1335. http:// www.jlr.org/content/40/7/1328.long

Murea, M., Ma, L., and Freedman, B. I. (2012). Genetic and environmental factors associated with type 2 diabetes and diabetic vascular complications. Rev Diabet Stud 9, 6-22. http:// dx.doi.org/10.1900/RDS.2012.9.6

Nanthakumar, K., Jalife, J., Masse, S., et al. (2007). Optical mapping of Langendorff-perfused human hearts: establishing a model for the study of ventricular fibrillation in humans. Am J Physiol Heart Circ Physiol 293, H875-880. http://dx.doi. org/10.1152/ajpheart.01415.2006

Nesher, R. and Cerasi, E. (2002). Modeling phasic insulin release: immediate and time-dependent effects of glucose. Diabetes 51, Suppl 1, S53-59. http://dx.doi.org/10.2337/ diabetes.51.2007.S53

Neubauer, N. and Kulkarni, R. N. (2006). Molecular approaches to study control of glucose homeostasis. Ilar J 47, 199-211. http://dx.doi.org/10.1093/ilar.47.3.199

Nishina, P. M., Naggert, J. K., Verstuyft, J., et al . (1994). Atherosclerosis in genetically obese mice: the mutants obese, diabetes, fat, tubby, and lethal yellow. Metabolism 43, 554-558. http://dx.doi.org/10.1016/0026-0495(94)90195-3

Nissen, S. E. and Wolski, K. (2010). Rosiglitazone revisited: an updated meta-analysis of risk for myocardial infarction and cardiovascular mortality. Arch Intern Med 170, 1191-1201. http://dx.doi.org/10.1001/archinternmed.2010.207

Nitert, M. D., Dayeh, T., Volkov, P., et al. (2012). Impact of an exercise intervention on DNA methylation in skeletal muscle from first-degree relatives of patients with type 2 diabetes. $D i$ abetes 61, 3322-3332. http://dx.doi.org/10.2337/db11-1653

Nunemaker, C. S., Wasserman, D. H., McGuinness, O. P., et al. (2006). Insulin secretion in the conscious mouse is biphasic and pulsatile. Am J Physiol Endocrinol Metab 290, E523-529. http://dx.doi.org/10.1152/ajpendo.00392.2005

Odom, D. T., Dowell, R. D., Jacobsen, E. S., et al. (2007). Tissue-specific transcriptional regulation has diverged significantly between human and mouse. Nat Genet 39, 730-732. http://dx.doi.org/10.1038/ng2047

Orci, L., Ravazzola, M., Baetens, D., et al. (1990). Evidence that down-regulation of beta-cell glucose transporters in noninsulin-dependent diabetes may be the cause of diabetic hyperglycemia. Proc Natl Acad Sci U S A 87, 9953-9957. http:// dx.doi.org/10.1073/pnas.87.24.9953

Otonkoski, T., Banerjee, M., Korsgren, O., et al. (2008). Unique basement membrane structure of human pancreatic islets: implications for beta-cell growth and differentiation. Diabetes Obes Metab 10, Suppl 4, 119-127. http://dx.doi.org/10.1111/ j.1463-1326.2008.00955.x

Owerbach, D., Bell, G. I., Rutter, W. J., et al. (1980). The insulin gene is located on chromosome 11 in humans. Nature 286, 82-84. http://dx.doi.org/10.1038/286082a0

Pan, X. R., Li, G. W., Hu, Y. H., et al. (1997). Effects of diet and exercise in preventing NIDDM in people with impaired glucose tolerance. The Da Qing IGT and diabetes study. Diabetes Care 20, 537-544. http://dx.doi.org/10.2337/diacare.20.4.537 Parnaud, G., Bosco, D., Berney, T., et al. (2008). Proliferation 
of sorted human and rat beta cells. Diabetologia 51, 91-100. http://dx.doi.org/10.1007/s00125-007-0855-1

Patek, S. D., Bequette, B. W., Breton, M., et al. (2009). In silico preclinical trials: methodology and engineering guide to closedloop control in type 1 diabetes mellitus.J Diabetes Sci Technol 3, 269-282. http://dx.doi.org/10.1177/193229680900300207

Pederson, B. A., Schroeder, J. M., Parker, G. E., et al. (2005). Glucose metabolism in mice lacking muscle glycogen synthase. Diabetes 54, 3466-3473. http://dx.doi.org/10.2337/ diabetes.54.12.3466

Pellizzon, M. A. (2008). Diet-induced atherosclerosis/hypercholesterolemia in rodent models. http://bit.ly/1aRIcKz

Petersen, K. F. and Shulman, G. I. (2002). Cellular mechanism of insulin resistance in skeletal muscle. $J R$ Soc Med 95, Suppl 42, 8-13. http://www.ncbi.nlm.nih.gov/pmc/articles/ PMC1308947/

Petit, P., Hillaire-Buys, D., Manteghetti, M., et al. (1998). Evidence for two different types of $\mathrm{P} 2$ receptors stimulating insulin secretion from pancreatic B cell. Br J Pharmacol 125, 1368-1374. http://dx.doi.org/10.1038/sj.bjp.0702214

Ploug, T. and Vinten, J. (2006). Counterpoint: Glucose phosphorylation is not a significant barrier to glucose uptake by the working muscle. J Appl Physiol 101, 18051806; discussion 1806-1808. http://dx.doi.org/10.1152/ japplphysiol.00817b.2006

Poulsen, C. R., Bokvist, K., Olsen, H. L., et al. (1999). Multiple sites of purinergic control of insulin secretion in mouse pancreatic beta-cells. Diabetes 48, 2171-2181. http://dx.doi. org/10.2337/diabetes.48.11.2171

Ravassard, P., Hazhouz, Y., Pechberty, S., et al. (2011). A genetically engineered human pancreatic beta cell line exhibiting glucose-inducible insulin secretion. J Clin Invest 121, 35893597. http://dx.doi.org/10.1172/JCI58447

Ritzel, R. A., Meier, J. J., Lin, C. Y., et al. (2007). Human islet amyloid polypeptide oligomers disrupt cell coupling, induce apoptosis, and impair insulin secretion in isolated human islets. Diabetes 56, 65-71. http://dx.doi.org/10.2337/db060734

Robinson, R., Barathi, V. A., Chaurasia, S. S., et al. (2012). Update on animal models of diabetic retinopathy: from molecular approaches to mice and higher mammals. Dis Model Mech 5, 444-456. http://dx.doi.org/10.1242/dmm.009597

Roden, M., Petersen, K. F., and Shulman, G. I. (2001). Nuclear magnetic resonance studies of hepatic glucose metabolism in humans. Recent Prog Horm Res 56, 219-237. http://dx.doi. org/10.1210/rp.56.1.219

Roderigo-Milne, H., Hauge-Evans, A. C., Persaud, S. J., et al. (2002). Differential expression of insulin genes 1 and 2 in MIN6 cells and pseudoislets. Biochem Biophys Res Commun 296, 589-595. http://dx.doi.org/10.1016/S0006291X(02)00913-0

Rodriguez-Diaz, R., Abdulreda, M. H., Formoso, A. L., et al. (2011a). Innervation patterns of autonomic axons in the human endocrine pancreas. Cell Metab 14, 45-54. http://dx.doi. org/10.1016/j.cmet.2011.05.008

Rodriguez-Diaz, R., Dando, R., Jacques-Silva, M. C., et al. (2011b). Alpha cells secrete acetylcholine as a non-neuronal paracrine signal priming beta cell function in humans. Nat Med 17, 888-892. http://dx.doi.org/10.1038/nm.2371

Rodriguez-Diaz, R., Dando, R., Huang, Y. A., et al. (2012). Real-time detection of acetylcholine release from the human endocrine pancreas. Nat Protoc 7, 1015-1023. http://dx.doi. org/10.1038/nprot.2012.040

Roep, B. O., Atkinson, M., and von Herrath, M. (2004). Satisfaction (not) guaranteed: re-evaluating the use of animal models of type 1 diabetes. Nat Rev Immunol 4, 989-997. http://dx.doi. org/10.1038/nri1502

Rorsman, P. and Braun, M. (2013). Regulation of insulin secretion in human pancreatic islets. Annu Rev Physiol 75, 155-179. http://dx.doi.org/10.1146/annurev-physiol-030212-183754

Rossmeisl, M., Rim, J. S., Koza, R. A., et al. (2003). Variation in type 2 diabetes-related traits in mouse strains susceptible to diet-induced obesity. Diabetes 52, 1958-1966. http://dx.doi. org/10.2337/diabetes.52.8.1958

Sansbury, F. H., Flanagan, S. E., Houghton, J. A., et al. (2012). SLC2A2 mutations can cause neonatal diabetes, suggesting GLUT2 may have a role in human insulin secretion. Diabetologia 55, 2381-2385. http://dx.doi.org/10.1007/s00125-0122595-0

Santer, R., Schneppenheim, R., Dombrowski, A., et al. (1997). Mutations in GLUT2, the gene for the liver-type glucose transporter, in patients with Fanconi-Bickel syndrome. Nat Genet 17, 324-326. http://dx.doi.org/10.1038/ng1197-324

Santer, R., Schneppenheim, R., Suter, D., et al. (1998). FanconiBickel syndrome - the original patient and his natural history, historical steps leading to the primary defect, and a review of the literature. Eur J Pediatr 157, 783-797. http://dx.doi. org/10.1007/s004310050937

Santos, R. M., Rosario, L. M., Nadal, A., et al. (1991). Widespread synchronous $\left[\mathrm{Ca}^{2+}\right]$ i oscillations due to bursting electrical activity in single pancreatic islets. Pflugers Arch 418 , 417-422. http://dx.doi.org/10.1007/BF00550880

Sanyal, A., Lajoie, B. R., Jain, G., et al. (2012). The long-range interaction landscape of gene promoters. Nature 489, 109113. http://dx.doi.org/10.1038/nature11279

Schafer, M. K., Hartwig, N. R., Kalmbach, N., et al. (2013). Species-specific vesicular monoamine transporter 2(VMAT2) expression in mammalian pancreatic beta cells: implications for optimising radioligand-based human beta cell mass (BCM) imaging in animal models. Diabetologia 56, 10471056. http://dx.doi.org/10.1007/s00125-013-2847-7

Scheen, A. J. (2001). Thiazolidinediones and liver toxicity. Diabetes Metab 27, 305-313. http://www.em-consulte.com/ article/80010/alertePM

Schilling, M. M., Oeser, J. K., Chandy, J. K., et al. (2008). Sequence variation between the mouse and human glucose6-phosphatase catalytic subunit gene promoters results in differential activation by peroxisome proliferator activated receptor gamma coactivator-1alpha. Diabetologia 51, 15051514. http://dx.doi.org/10.1007/s00125-008-1050-8

Schmidt, S. F., Jorgensen, M., Sandelin, A., et al . (2012). Crossspecies ChIP-seq studies provide insights into regulatory strategies of PPARgamma in adipocytes. Transcription 3, 1924. http://dx.doi.org/10.4161/trns.3.1.19302 
Schrem, H., Klempnauer, J., and Borlak, J. (2004). Liver-enriched transcription factors in liver function and development. Part II: the C/EBPs and D site-binding protein in cell cycle control, carcinogenesis, circadian gene regulation, liver regeneration, apoptosis, and liver-specific gene regulation. Pharmacol Rev 56, 291-330. http://dx.doi.org/10.1124/pr.56.2.5

Seok, J., Warren, H. S., Cuenca, A. G., et al. (2012). Genomic responses in mouse models poorly mimic human inflammatory diseases. Proc Natl Acad Sci U S A 110, 3507-3512. http:// dx.doi.org/10.1073/pnas.1222878110

Sharma, A. K. and Thomas, P. K. (1974). Peripheral nerve structure and function in experimental diabetes. J Neurol Sci 23, 1-15. http://dx.doi.org/10.1016/0022-510X(74)90136-1

Shiota, C., Larsson, O., Shelton, K. D., et al. (2002). Sulfonylurea receptor type 1 knock-out mice have intact feeding-stimulated insulin secretion despite marked impairment in their response to glucose. J Biol Chem 277, 37176-37183. http:// dx.doi.org/10.1074/jbc.M206757200

Shulman, G. I., Rothman, D. L., Jue, T., et al. (1990). Quantitation of muscle glycogen synthesis in normal subjects and subjects with non-insulin-dependent diabetes by $13 \mathrm{C}$ nuclear magnetic resonance spectroscopy. N Engl J Med 322, 223228. http://dx.doi.org/10.1056/NEJM199001253220403

Smith, B. K., West, D. B., and York, D. A. (1997). Carbohydrate versus fat intake: differing patterns of macronutrient selection in two inbred mouse strains. Am J Physiol 272, R357-362. http://ajpregu.physiology.org/content/272/1/R357

Smith, M. T. (2003). Mechanisms of troglitazone hepatotoxicity. Chem Res Toxicol 16, 679-687. http://dx.doi.org/10.1021/ tx034033e

Soares, M. B., Schon, E., Henderson, A., et al. (1985). RNAmediated gene duplication: the rat preproinsulin I gene is a functional retroposon. Mol Cell Biol 5, 2090-2103. http:// www.ncbi.nlm.nih.gov/pmc/articles/PMC366927/

Soleimanpour, S. A., Crutchlow, M. F., Ferrari, A. M., et al. (2010). Calcineurin signaling regulates human islet \{beta\}cell survival. J Biol Chem 285, 40050-40059. http://dx.doi. org/10.1074/jbc.M110.154955

Srinivasan, K. and Ramarao, P. (2007). Animal models in type 2 diabetes research: an overview. Indian J Med Res 125, 451472.

Stephenne, X., Foretz, M., Taleux, N., et al. (2011). Metformin activates AMP-activated protein kinase in primary human hepatocytes by decreasing cellular energy status. Diabetologia 54, 3101-3110. http://dx.doi.org/10.1007/s00125-0112311-5

Szkudelski, T., Kandulska, K., and Okulicz, M. (1998). Alloxan in vivo does not only exert deleterious effects on pancreatic B cells. Physiol Res 47, 343-346. http://www.biomed.cas.cz/ physiolres/pdf/47/47_343.pdf

Takahashi, N., Kadowaki, T., Yazaki, Y., et al. (1999). Postpriming actions of ATP on $\mathrm{Ca}^{2+}$-dependent exocytosis in pancreatic beta cells. Proc Natl Acad Sci U S A 96, 760-765. http://dx.doi.org/10.1073/pnas.96.2.760

Taylor, C. and Hobbs, F. D. (2009). Type 2 diabetes, thiazolidinediones, and cardiovascular risk. Br J Gen Pract 59, 520-524. http://dx.doi.org/10.3399/bjgp09X453440
Thliveris, J. A., Paz, G. F., Rempel, E., et al. (1984). An extrapancreatic direct effect of streptozotocin on the hypothalamohypophyseal-testicular axis in the rat. Anat Anz 157, 213219.

Thorens, B., Wu, Y. J., Leahy, J. L., et al. (1992). The loss of GLUT2 expression by glucose-unresponsive beta cells of $\mathrm{db} / \mathrm{db}$ mice is reversible and is induced by the diabetic environment. J Clin Invest 90, 77-85. http://dx.doi.org/10.1172/ JCI115858

Timchenko, N., Wilson, D. R., Taylor, L. R., et al. (1995). Autoregulation of the human $\mathrm{C} / \mathrm{EBP}$ alpha gene by stimulation of upstream stimulatory factor binding. Mol Cell Biol 15, 1192-1202. http://mcb.asm.org/content/15/3/1192.long

Towler, M. C., Gleeson, P. A., Hoshino, S., et al. (2004a). Clathrin isoform $\mathrm{CHC} 22$, a component of neuromuscular and myotendinous junctions, binds sorting nexin 5 and has increased expression during myogenesis and muscle regeneration. Mol Biol Cell 15, 3181-3195. http://dx.doi.org/10.1091/mbc.E0403-0249

Towler, M. C., Kaufman, S. J., and Brodsky, F. M. (2004b). Membrane traffic in skeletal muscle. Traffic 5, 129-139. http://dx.doi.org/10.1111/j.1600-0854.2003.00164.x

Unger, R. H. and Cherrington, A. D. (2012). Glucagonocentric restructuring of diabetes: a pathophysiologic and therapeutic makeover. J Clin Invest 122, 4-12. http://dx.doi.org/10.1172/ JCI60016

Valdeolmillos, M., Santos, R. M., Contreras, D., et al. (1989). Glucose-induced oscillations of intracellular $\mathrm{Ca}^{2+}$ concentration resembling bursting electrical activity in single mouse islets of Langerhans. FEBS Lett 259, 19-23. http://dx.doi. org/10.1016/0014-5793(89)81484-X

Valera, A., Solanes, G., Fernandez-Alvarez, J., et al. (1994). Expression of GLUT-2 antisense RNA in beta cells of transgenic mice leads to diabetes. J Biol Chem 269, 28543-28546. http:// www.jbc.org/content/269/46/28543.long

Van Gaal, L. F., Mertens, I. L., and De Block, C. E. (2006). Mechanisms linking obesity with cardiovascular disease. $\mathrm{Na}$ ture 444, 875-880. http://dx.doi.org/10.1038/nature05487

Vassilopoulos, S., Esk, C., Hoshino, S., et al. (2009). A role for the CHC22 clathrin heavy-chain isoform in human glucose metabolism. Science 324, 1192-1196. http://dx.doi. org/10.1126/science.1171529

Velloso, L. A., Folli, F., Perego, L., et al. (2006). The multifaceted cross-talk between the insulin and angiotensin II signaling systems. Diabetes Metab Res Rev 22, 98-107. http:// dx.doi.org/10.1002/dmrr.611

Volkmar, M., Dedeurwaerder, S., Cunha, D. A., et al. (2012). DNA methylation profiling identifies epigenetic dysregulation in pancreatic islets from type 2 diabetic patients. Embo $J$ 31, 1405-1426. http://dx.doi.org/10.1038/emboj.2011.503

Wakeham, D. E., Abi-Rached, L., Towler, M. C., et al. (2005). Clathrin heavy and light chain isoforms originated by independent mechanisms of gene duplication during chordate evolution. Proc Natl Acad Sci U S A 102, 7209-7214. http:// dx.doi.org/10.1073/pnas.0502058102

Walpita, D., Hasaka, T., Spoonamore, J., et al. (2012). A human islet cell culture system for high-throughput 
screening. J Biomol Screen 17, 509-518. http://dx.doi. org/10.1177/1087057111430253

Wang, C. C., Adochio, R. L., Leitner, J. W., et al. (2013). Acute effects of different diet compositions on skeletal muscle insulin signalling in obese individuals during caloric restriction. Metabolism 62, 595-603. http://dx.doi.org/10.1016/ j.metabol.2012.10.010

Warden, C. H. and Fisler, J. S. (2008). Comparisons of diets used in animal models of high-fat feeding. Cell Metab 7, 277. http://dx.doi.org/10.1016/j.cmet.2008.03.014

Watada, H., Kajimoto, Y., Kaneto, H., et al. (1996). Involvement of the homeodomain-containing transcription factor PDX-1 in islet amyloid polypeptide gene transcription. Biochem Biophys Res Commun 229, 746-751. http://dx.doi.org/10.1006/ bbrc. 1996.1875

Wendt, T., Harja, E., Bucciarelli, L., et al. (2006). RAGE modulates vascular inflammation and atherosclerosis in a murine model of type 2 diabetes. Atherosclerosis 185, 70-77. http:// dx.doi.org/10.1016/j.atherosclerosis.2005.06.013

Wentworth, B. M., Schaefer, I. M., Villa-Komaroff, L., et al. (1986). Characterization of the two nonallelic genes encoding mouse preproinsulin. J Mol Evol 23, 305-312. http://dx.doi. org/10.1007/BF02100639

Wentworth, B. M., Rhodes, C., Schnetzler, B., et al. (1992). The ratio of mouse insulin I:insulin II does not reflect that of the corresponding preproinsulin mRNAs. Mol Cell Endocrinol 86, 177-186. http://dx.doi.org/10.1016/0303-7207(92)90142-S

West, D. B., Boozer, C. N., Moody, D. L., et al. (1992). Dietary obesity in nine inbred mouse strains. Am J Physiol 262, R1025-1032. http://ajpregu.physiology.org/cgi/pmidlookup? view $=$ reprint $\&$ pmid $=1621856$

Westermark, P., Engstrom, U., Johnson, K. H., et al. (1990). Islet amyloid polypeptide: pinpointing amino acid residues linked to amyloid fibril formation. Proc Natl Acad Sci U S A 87, 5036-5040. http://dx.doi.org/10.1073/pnas.87.13.5036

Westermark, P., Andersson, A., and Westermark, G. T. (2011). Islet amyloid polypeptide, islet amyloid, and diabetes mellitus. Physiol Rev 91, 795-826. http://dx.doi.org/10.1152/ physrev.00042.2009

Wild, S., Roglic, G., Green, A., et al. (2004). Global prevalence of diabetes: estimates for the year 2000 and projections for 2030. Diabetes Care 27, 1047-1053. http://dx.doi. org/10.2337/diacare.27.5.1047

Wilson, M. D., Barbosa-Morais, N. L., Schmidt, D., et al. (2008). Species-specific transcription in mice carrying human chromosome 21. Science 322, 434-438. http://dx.doi.org/10.1126/ science. 1160930

Yang, B. T., Dayeh, T. A., Volkov, P. A., et al. (2012). Increased DNA methylation and decreased expression of PDX-1 in pancreatic islets from patients with type 2 diabetes. Mol Endocrinol 26, 1203-1212. http://dx.doi.org/10.1210/me.2012-1004

Zawalich, W. S., Zawalich, K. C., and Kelley, G. G. (1995). Regulation of insulin release by phospholipase $\mathrm{C}$ activation in mouse islets: differential effects of glucose and neurohumoral stimulation. Endocrinology 136, 4903-4909. http://dx.doi. org/10.1210/endo.136.11.7588223

Zawalich, W. S. and Zawalich, K. C. (1996a). Species differences in the induction of time-dependent potentiation of insulin secretion. Endocrinology 137, 1664-1669. http://dx.doi. org/10.1210/endo.137.5.8612499

Zawalich, W. S. and Zawalich, K. C. (1996b). Regulation of insulin secretion by phospholipase C. Am J Physiol 271, E409416. http://ajpendo.physiology.org/content/271/3/E409

Zawalich, W. S., Bonnet-Eymard, M., and Zawalich, K. C. (1998). Glucose-induced desensitization of the pancreatic beta-cell is species dependent. Am J Physiol 275, E917-924. http://ajpendo.physiology.org/content/275/6/E917.article-info

Zawalich, W. S., Bonnet-Eymard, M., and Zawalich, K. C. (2000). Insulin secretion, inositol phosphate levels, and phospholipase $\mathrm{C}$ isozymes in rodent pancreatic islets. Metabolism 49, 1156-1163. http://dx.doi.org/10.1053/meta.2000.8613

Zawalich, W. S., Zawalich, K. C., Tesz, G. J., et al. (2001). Insulin secretion and IP levels in two distant lineages of the genus Mus: comparisons with rat islets. Am J Physiol Endocrinol Metab 280, E720-728. http://ajpendo.physiology.org/ content/280/5/E720

Zhang, Q., Bengtsson, M., Partridge, C., et al. (2007). R-type $\mathrm{Ca}^{2+}$-channel-evoked CICR regulates glucose-induced somatostatin secretion. Nat Cell Biol 9, 453-460. http://dx.doi. org/10.1038/ncb1563

Zierath, J. R., Krook, A., and Wallberg-Henriksson, H. (2000). Insulin action and insulin resistance in human skeletal muscle. Diabetologia 43, 821-835. http://dx.doi.org/10.1007/ s001250051457

Zimmet, P., Alberti, K. G., and Shaw, J. (2001). Global and societal implications of the diabetes epidemic. Nature 414, 782 787. http://dx.doi.org/10.1038/414782a

\section{Acknowlegement}

The authors would like to thank Dr Neal D. Barnard for helpful discussions and critical reading of the manuscript.

\section{Declarations/conflict of interest}

None

\section{Correspondence to}

Charu Chandrasekera, $\mathrm{PhD}$

Physicians Committee for Responsible Medicine

5100 Wisconsin Avenue NW, Suite 400

Washington DC 20016

USA

Phone: +1 2025277381

e-mail: cchandrasekera@pcrm.org 